Review

\title{
Social Robots in Hospitals: A Systematic Review
}

\author{
Carina Soledad González-González ${ }^{1, * \mathbb{D}}$, Verónica Violant-Holz ${ }^{2}$ (D) and Rosa Maria Gil-Iranzo $^{3}$ \\ 1 Departamento de Ingeniería Informática y de Sistemas, Escuela de Ingeniería y Tecnología, \\ Universidad de La Laguna, 38204 La Laguna, Spain \\ 2 Department of Didactic and Educational Organization, Faculty of Education, International Observatory in \\ Hospital Pedagogy, Universitat de Barcelona, 08035 Barcelona, Spain; vviolant@ub.edu \\ 3 Departamento de Informática e Ingeniería Industrial, Escuela Politécnica Superior, Universitat de Lleida, \\ 25001 Lleida, Spain; rosamaria.gil@udl.cat \\ * Correspondence: cjgonza@ull.edu.es
}

check for

updates

Citation: González-González, C.S.; Violant-Holz, V.; Gil-Iranzo, R.M. Social Robots in Hospitals: A Systematic Review. Appl. Sci. 2021, 11, 5976. https://doi.org/10.3390/ app11135976

Academic Editor: Manuel Armada

Received: 15 April 2021

Accepted: 24 June 2021

Published: 27 June 2021

Publisher's Note: MDPI stays neutral with regard to jurisdictional claims in published maps and institutional affiliations.

Copyright: (c) 2021 by the authors. Licensee MDPI, Basel, Switzerland. This article is an open access article distributed under the terms and conditions of the Creative Commons Attribution (CC BY) license (https:/ / creativecommons.org/licenses/by/ $4.0 /)$.

\begin{abstract}
Hospital environments are facing new challenges this century. One of the most important is the quality of services to patients. Social robots are gaining prominence due to the advantages they offer; in particular, several of their main uses have proven beneficial during the pandemic. This study aims to shed light on the current status of the design of social robots and their interaction with patients. To this end, a systematic review was conducted using WoS and MEDLINE, and the results were exhaustive analyzed. The authors found that most of the initiatives and projects serve the elderly and children, and specifically, that they helped these groups fight diseases such as dementia, autism spectrum disorder (ASD), cancer, and diabetes.
\end{abstract}

Keywords: social robot; design; interaction; hospital; healthcare

\section{Introduction}

In recent times, the academic community has taken a growing interest in human-robot interaction (HRI), particularly with social robots [1]. This field is dedicated to identifying, creating, and assessing robots and their interactions with people [2]. HRI includes computer science, engineering, psychology, and other areas of study involving these systems and social behaviors [1].

Social robots can help with long-term healthcare services, such as rehabilitation [3] or school attendance [4]; however, access to this technology requires a regulatory and ethical framework in the area of robotics research [3]. Assistive Ambient Living (AAL) supports healthcare services at home with e-tools and projects like ULISSE or ENRICHME, although the use of an interactive robot raises privacy and ethical concerns [5].

During the COVID-19 pandemic, society saw social robots being implemented in real settings and different applications [6]. The lockdown and the various measures adopted in countries, such as physical distancing and isolation, provided an opportunity to apply social robots as assistive tools during the pandemic, specifically in healthcare services [7].

As a result, social robots were crucial in reducing the spread of COVID-19 by performing certain functions like monitoring and supporting patients and healthcare professionals [8]. Furthermore, research has provided evidence that isolation and lockdowns have negatively impacted mental health and wellbeing [9], meaning social robots might be effective in helping and promoting wellbeing during a pandemic [10].

However, there are many unanswered questions involving the design of social robots as concerns their safety and the ethical principles involved in using them in healthcare settings. The research into their main uses and applications in hospitals is also lacking. For these reasons, in this paper, we will try to answer the following questions:

RQ1: How are social robots designed? Are they ethically designed?

RQ2: What are the main uses and applications of social robots in healthcare? 
Our first research question involves three perspectives: design, interaction, and ethical issues. It is essential to determine what studies exist on the design of the software and hardware of social robots, so RQ1 seeks to shed light on this issue. Additionally, interaction is an essential ingredient in the development of social robots because they communicate and interact with human beings. RQ2 analyzes only that, while RQ1 addresses concerns involving social robots, with interaction and intelligence aspects being critical [11].

Thus, in this paper, we conduct a systematic review to answer these questions, focusing on the design of social robots and their applications in hospitals. We also provide the context and use of social robots in healthcare, answering the questions of what is being done and how they are being used. In addition, we analyze the ethical component in the design of social robots.

The paper is organized into several sections. Section 2 presents the methodology employed, and the results are presented in Section 3. Section 4 discusses the results in terms of the research questions. Finally, the conclusions are presented to provide a roadmap for designers of social robots for healthcare services.

\section{Materials and Methods}

2.1. Design

This article focuses on peer-reviewed journal articles and systematic reviews involving social robots and hospitals published between 1 January 1960 and 31 March 2021.

\subsection{Databases and Search Strategy}

The Web of Sciences WoS and MEDLINE were searched on 11 March 2021. This search was refined in terms of the document type (article or early access or meeting or clinical trial or case report or review), language (English), and research areas (computer science or robotics or automation control systems or engineering or health care sciences services or psychology or social sciences, other topics or geriatrics gerontology or behavioral sciences or medical informatics or oncology or communication or telecommunications or information science, library science or education, educational research or pediatrics or social issues or neurosciences, neurology, or experimental medicine or urology, nephrology). An advanced search was conducted using these terms: (Social Robot * AND hospital *). The flow diagram was created as per the Preferred Reporting Items for Systematic Reviews and Meta-Analyses (PRISMA) [12] (see Figure 1).

\subsection{Inclusion/Exclusion Criteria for Selecting the Studies}

Two filters were used to identify eligible studies and ensure the reliability of the systematic review in the first screening. In the first filter, the three authors, using the consensus agreement [13], applied the first filter by screening eligible articles based on their titles and abstracts. With the resulting articles, each author independently applied the second filter and completed an inclusion/exclusion checklist while screening the titles, keywords, and abstracts resulting from the primary search. A qualitative analysis was conducted using consensus agreement to settle a disagreement in one session [13].

The articles reviewed were screened by title, keyword, and abstract and then classified into three categories: (a) articles or systematic reviews excluded for meeting exclusion criteria; (b) articles or systematic reviews excluded for meeting exclusion criteria but related to the subject; or (c) articles included because they satisfy all the inclusion criteria (Table 1). The full texts of the latter group were analyzed to answer two research questions. 


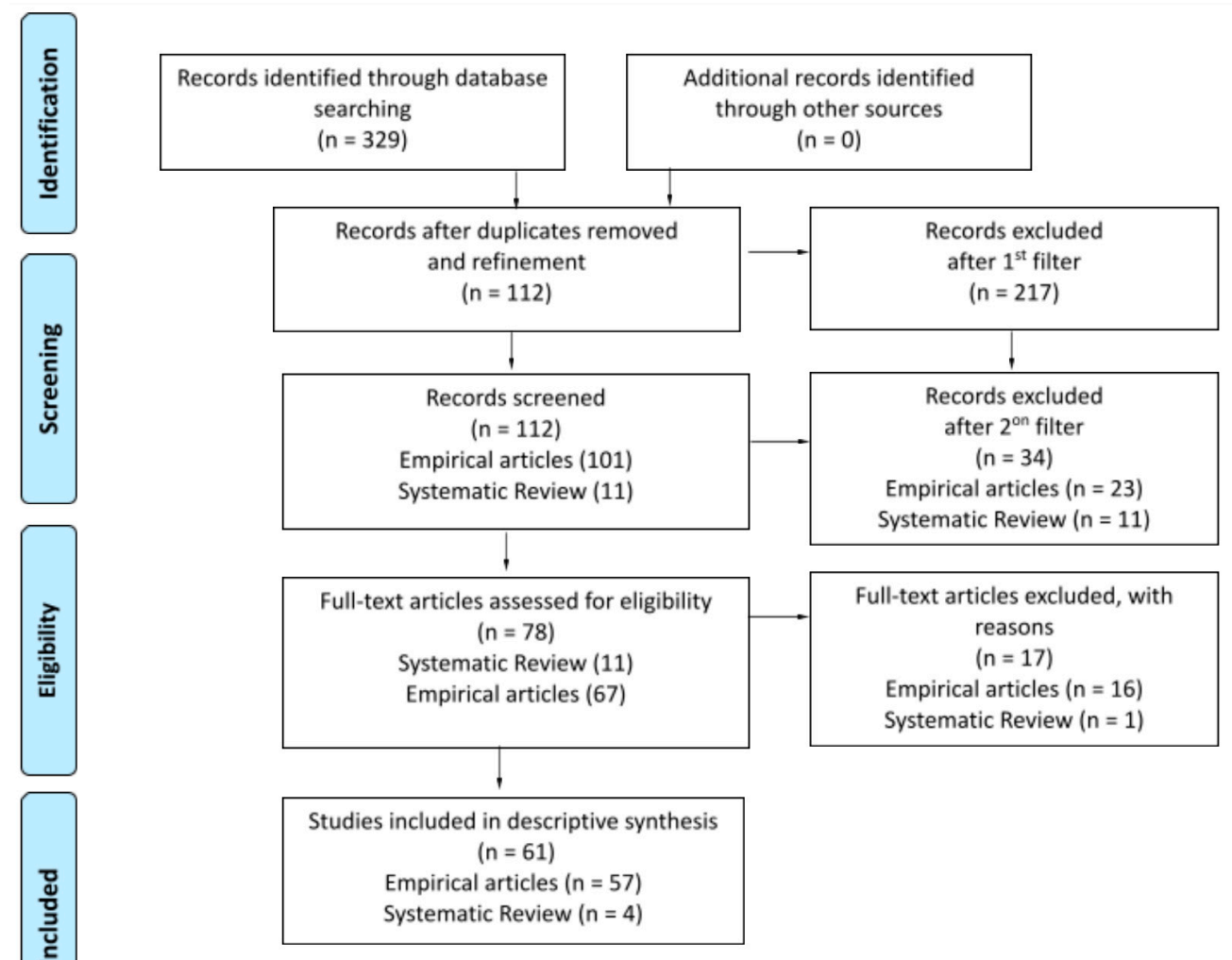

Figure 1. Flow diagram of the study selection process.

Table 1. Inclusion and Exclusion Criteria.

\section{Inclusion Criteria}

Exclusion Criteria

1. Type of publication: Empirical research and peer-reviewed articles and systematic reviews.

2. Study population: Participants of all ages. Participants with healthcare needs.

3. Keyword: hospitals.

4. Period: Published from 1 January 1960 to 31 March 2021.

5. Publication criterion: Written in English, any country.

1. Type of publication: No original data, such as reports, opinion studies, essays, or comments and no research.

2. No abstract available (first screening).

3. Study could not be retrieved (second screening).

\section{Results}

This search yielded 329 articles in two databases. After refinement involving document type, language, and research areas (Table 2), 112 articles passed the first screening. Based on the inclusion/exclusion criteria, we excluded 34 documents ( 23 empirical articles and 11 systematic reviews) with the second filter. Out of a total of 78 documents that were eligible to be read in full, 17 documents ( 16 empirical articles and 1 systematic review) were excluded after reading the full text for various reasons (13 studies could not be retrieved, 1 was written in a language other than English, 1 chapter, 1 collection of short, popular articles, 1 repeated). The total number of documents included in our review for analysis was 61 (57 empirical articles and 4 systematic reviews) (see Figure 1). Of all the papers analyzed, 22 were indexed in JCR $(\mathrm{Q} 1=5 ; \mathrm{Q} 2=5 ; \mathrm{Q} 3=8$; 4 4 =4), one in SJR (Q3), and 32 were published in proceedings. 
Table 2. Search results by research area.

\begin{tabular}{|c|c|}
\hline Research Area & Articles \\
\hline Computer science & 174 \\
\hline Robotics & 134 \\
\hline Automation control system & 127 \\
\hline Engineering & 124 \\
\hline Health care sciences services & 122 \\
\hline Psychology & 51 \\
\hline Social sciences other topics & 44 \\
\hline Geriatrics gerontology & 30 \\
\hline Behavioral sciences & 29 \\
\hline Medical informatics & 25 \\
\hline Oncology & 24 \\
\hline Communication & 23 \\
\hline Telecommunication & 23 \\
\hline Information science library science & 22 \\
\hline Education educational research & 18 \\
\hline Pediatrics & 18 \\
\hline Social issues & 18 \\
\hline Neurosciences, neurology & 17 \\
\hline Research experimental medicine & 17 \\
\hline Urology nephrology & 17 \\
\hline
\end{tabular}

A bibliometric analysis performed using Bibliometrix (an R-tool) and VOSViewer [14] was carried out on the 112 eligible documents after the first screening, that considered the importance of: 1 . The annual occurrences vs. years, 2. Evolution in time of titles and abstract terms, 3. Details of the child cluster, 4 . Details of clusters for older people, 5 . Healthcare connections, and 6. Factorial analysis corresponding to Multiple Correspondence Analysis (MCA), which yielded four stable factors.

An analysis of the 3198 terms (titles + abstracts) revealed the evolution in time using full counting, with the restriction of a minimum of 10 occurrences per term. Sixty-nine met the threshold. The $60 \%$ most relevant terms are shown in Figure 2, a total of 41 terms. For instance, social robotic, information and healthcare appear as terms used more since 2018, Figure 3. A detailed view of the Children cluster allows us to identify specific social robots (i.e., Pleo) and applications in some diseases (i.e., cancer and depression). The same process was used to find another user profile (older adult) (Figure 4). In Figure 5, a binary count was carried out with a total of 323 links and 3 main clusters, one of them being healthcare context. This figure shows the main connections (social robot with study, human robot interaction and assistive robot) as different ways to address healthcare environments from an engineering perspective. Figure 6 also reveals that design and interaction are key topics in defining the areas of expertise of social robots and that the selection of papers can help us answer our research questions. 


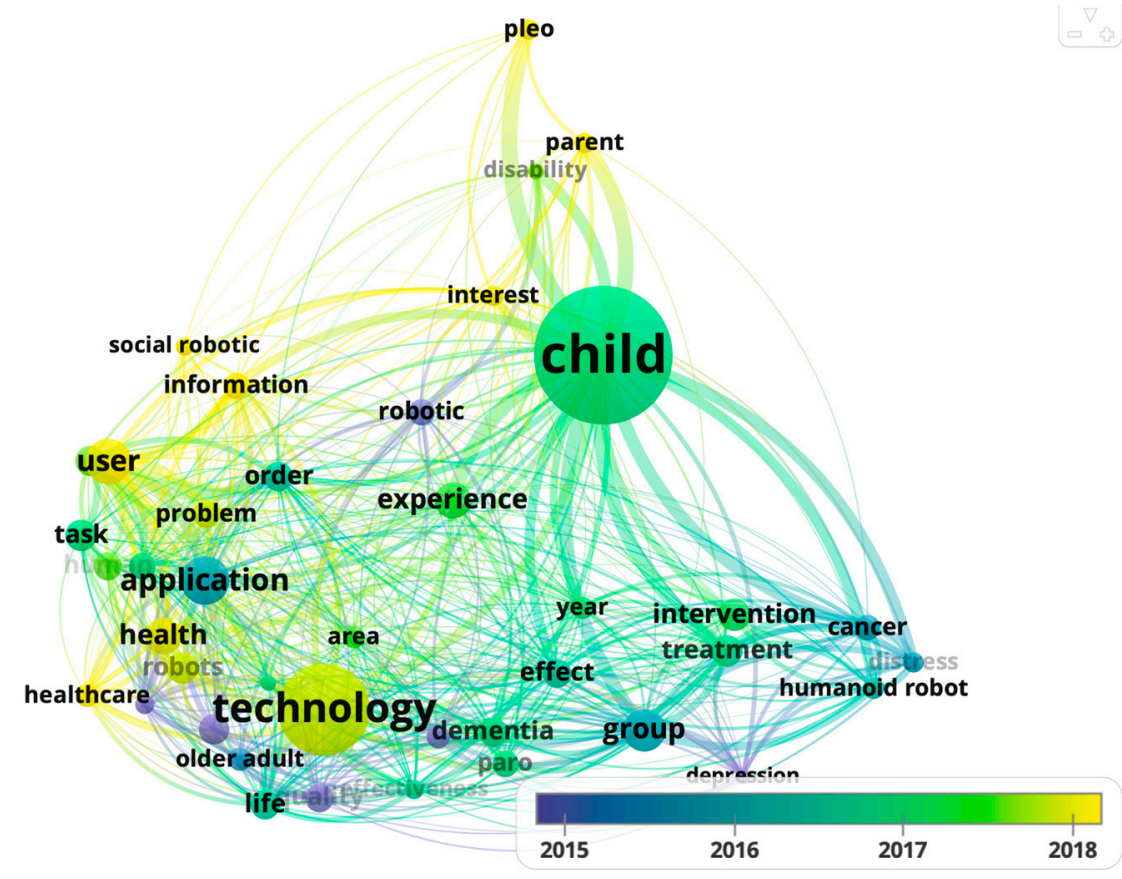

Figure 2. Evolution in time of titles and abstract terms.

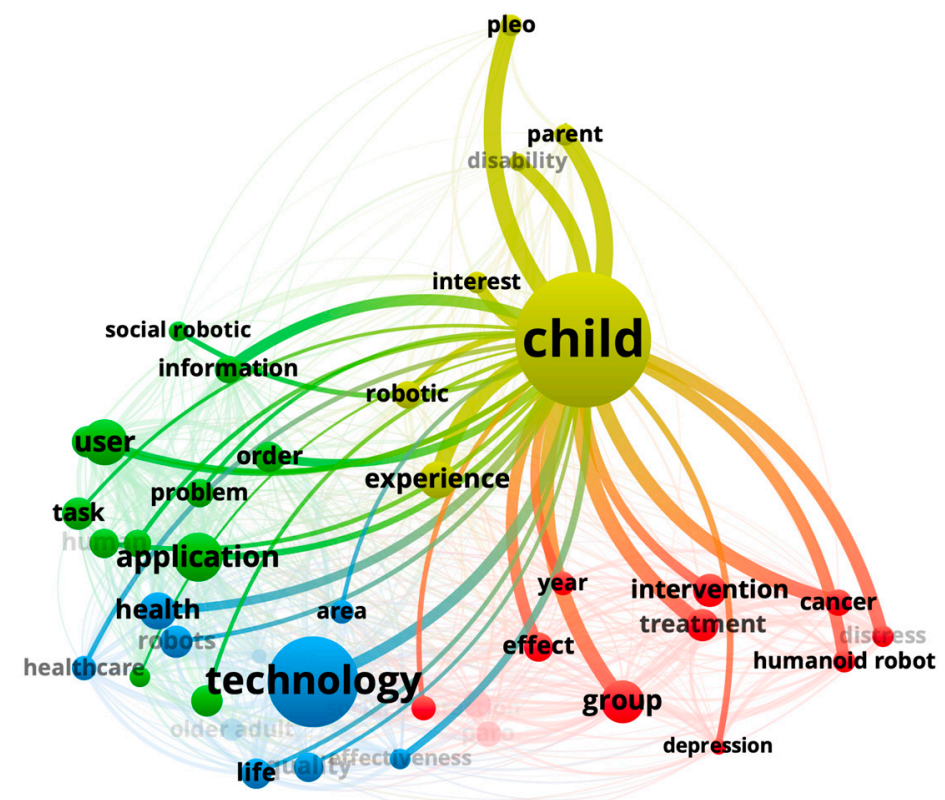

Figure 3. Details of the child cluster. 


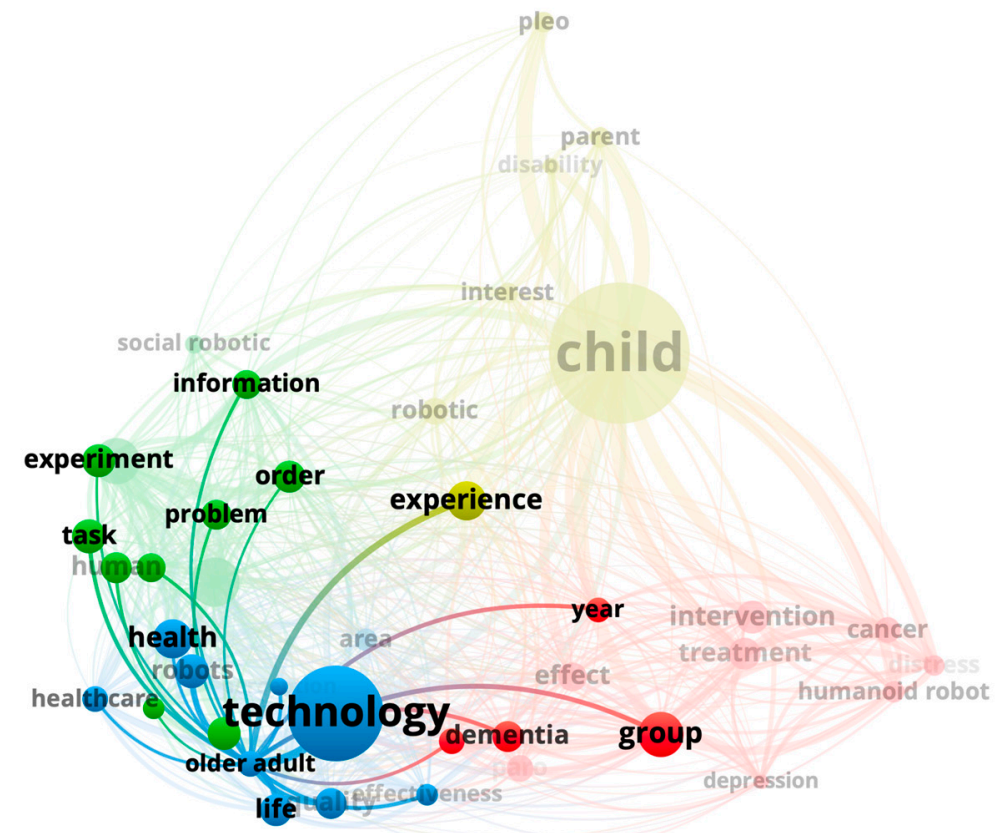

Figure 4. Details of the older adult cluster.

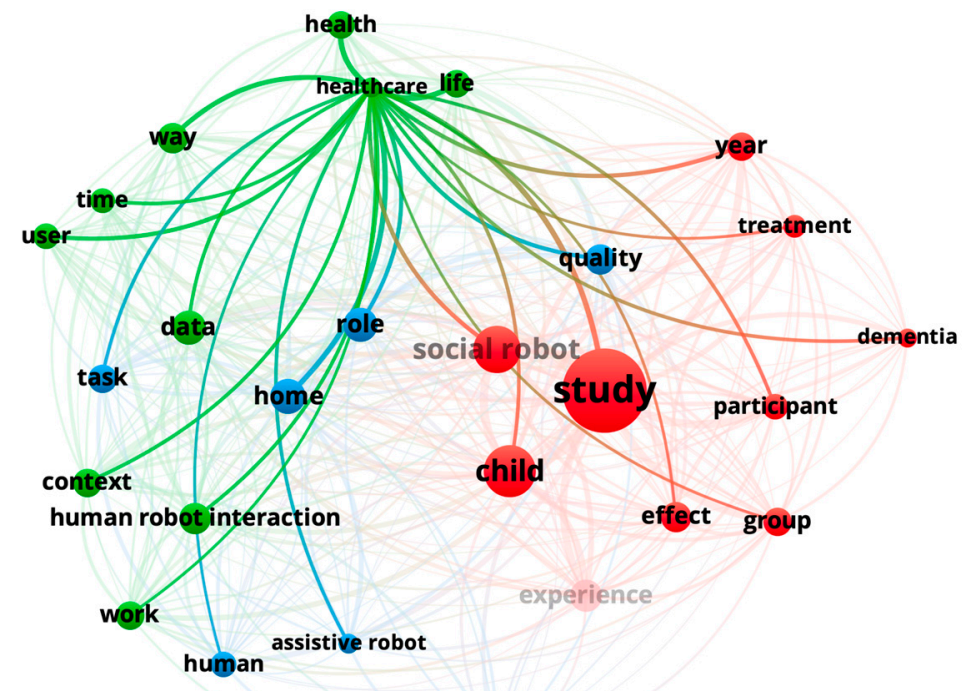

social interaction

Figure 5. Healthcare cluster.

Two tables are presented below. Table 3 includes the articles identified that address the first research question, while Table 4 contains the articles that address the second research question. Later in the paper, reference is made to how these articles, in some cases, can answer both questions. 


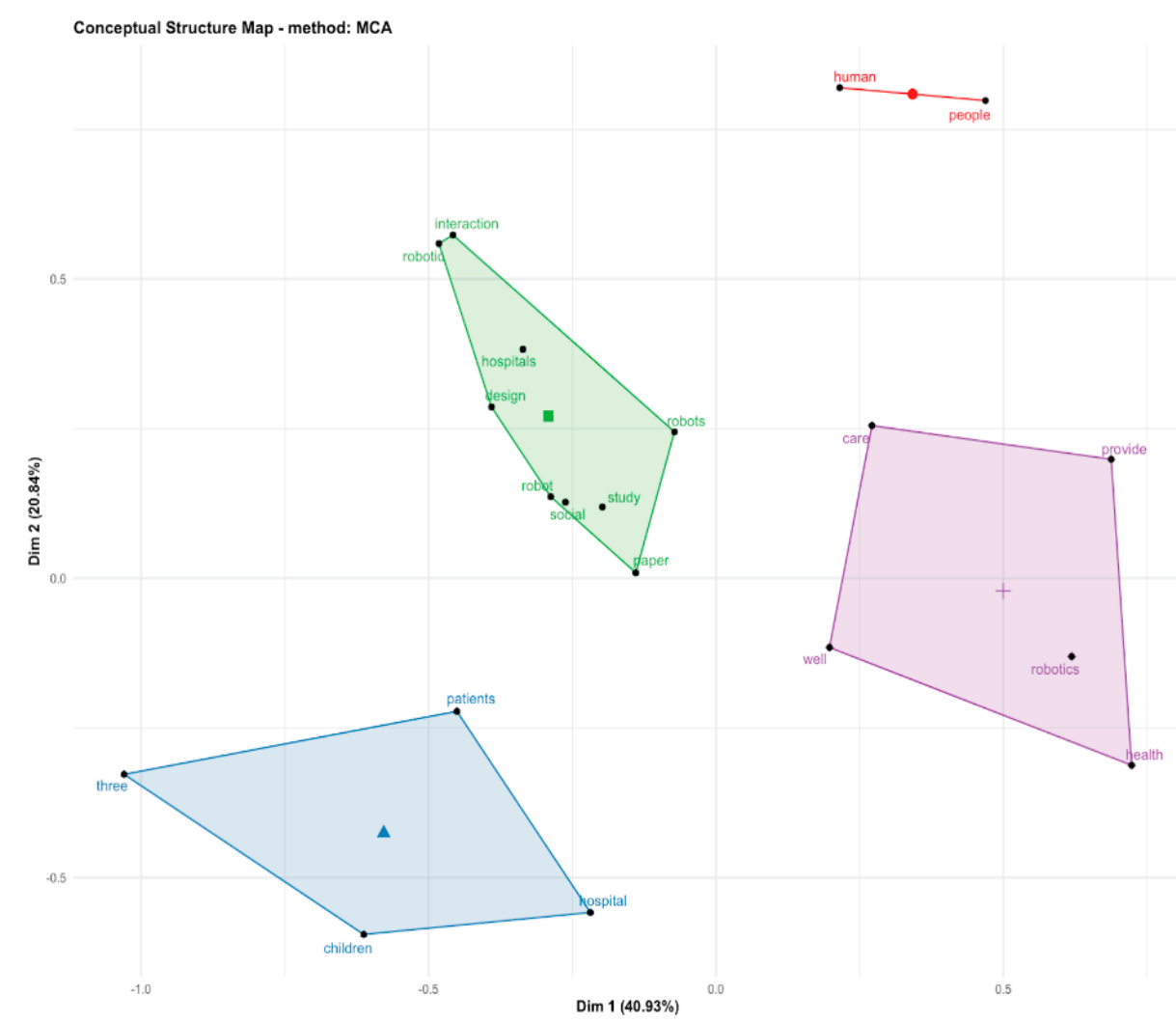

Figure 6. Factorial analysis corresponding to Multiple Correspondence Analysis (MCA). Four stable factors were found.

Table 3. Research question 1 (RQ1) on design approaches and main outcomes.

\begin{tabular}{|c|c|c|c|c|}
\hline Authors & Goals & Population & Concept Origin & Main Outcomes \\
\hline $\begin{array}{l}\text { Cross, Emily S.; Ramsey,) } \\
\text { Richard (2021) [15] }\end{array}$ & $\begin{array}{l}\text { To provide a framework to } \\
\text { classify all kinds of artificial } \\
\text { systems. }\end{array}$ & $\begin{array}{l}\text { Not applicable } \\
\text { (technical paper) }\end{array}$ & Study/Survey. & $\begin{array}{l}\text { A classification for artificial } \\
\text { systems based on parameters and } \\
\text { dimensions. Some factors can } \\
\text { influence the design, such as } \\
\text { expectations, cultural biases, and } \\
\text { changing perceptions. }\end{array}$ \\
\hline $\begin{array}{l}\text { Sheridan, Thomas B. } \\
\text { (2020) [16] }\end{array}$ & $\begin{array}{l}\text { To categorize research into } \\
\text { areas related to psychological } \\
\text { aspects, engineering, } \\
\text { assistance, and services. }\end{array}$ & $\begin{array}{l}\text { Not applicable } \\
\text { (technical paper) }\end{array}$ & $\begin{array}{l}\text { Review to enhance } \\
\text { psychology. }\end{array}$ & $\begin{array}{l}\text { Psychology appears as the critical } \\
\text { area for creating socially } \\
\text { acceptable robots that are } \\
\text { resourceful to human beings. }\end{array}$ \\
\hline $\begin{array}{l}\text { Ngo, Ha Quang Thinh; Le, } \\
\text { Van Nghia; Thien, Vu Dao } \\
\text { Nguyen; Nguyen, Thanh } \\
\text { Phuong; Nguyen, Hung } \\
\text { (2020) [17] }\end{array}$ & $\begin{array}{l}\text { To contribute to children's } \\
\text { wellbeing through interacting } \\
\text { with the PLEO robot, } \\
\text { connecting with parents or } \\
\text { tutors in the interaction } \\
\text { process, evolution of the } \\
\text { interaction, and the child's } \\
\text { psychological point of view. }\end{array}$ & $\begin{array}{c}\text { Children } \\
\text { (hospitalized) }\end{array}$ & $\begin{array}{l}\text { Contribution of PLEO } \\
\text { to the children's } \\
\text { wellbeing. }\end{array}$ & $\begin{array}{l}\text { PLEO's interaction came with } \\
\text { some behaviors (hugging, caring } \\
\text { or technical exploration, calmness, } \\
\text { activation, and/or making contact). } \\
\text { Interaction with PLEO elicited } \\
\text { positive emotions, like joy and } \\
\text { curiosity. Negative outcomes } \\
\text { when children did not observe the } \\
\text { behavior they expected. }\end{array}$ \\
\hline $\begin{array}{l}\text { Moerman, Clara J.; } \\
\text { Jansens, Rianne M. L. } \\
\text { (2020) [18] }\end{array}$ & $\begin{array}{l}\text { To address ethical issues } \\
\text { coming to healthcare } \\
\text { providers' attention involving } \\
\text { AAL technologies in the } \\
\text { elderly population. }\end{array}$ & $\begin{array}{l}\text { Not applicable } \\
\text { (addressed to } \\
\text { elderly) }\end{array}$ & $\begin{array}{l}\text { Assistive Ambient } \\
\text { Living (AAL) in } \\
\text { aging. }\end{array}$ & $\begin{array}{l}\text { Factors that affect the elderly: the } \\
\text { robot's role in caregiving, the } \\
\text { interaction, the robot's physical } \\
\text { appearance, ethics related to care, } \\
\text { what the robot can or cannot do, } \\
\text { and control over switching it off. }\end{array}$ \\
\hline
\end{tabular}


Table 3. Cont.

\begin{tabular}{|c|c|c|c|c|}
\hline Authors & Goals & Population & Concept Origin & Main Outcomes \\
\hline $\begin{array}{c}\text { Bartlett, Madeleine E.; } \\
\text { Costescu, Cristina; Baxter, } \\
\text { Paul; Thill, Serge (2020) } \\
\text { [19] }\end{array}$ & $\begin{array}{l}\text { To characterize the questions } \\
\text { that a social robot in the } \\
\text { physical world must deal with } \\
\text { to automate Autism Spectrum } \\
\text { Disorder (ASD) diagnoses. }\end{array}$ & Children (ASD) & $\begin{array}{l}\text { Social robot in the } \\
\text { physical world. }\end{array}$ & $\begin{array}{l}\text { Reliability and objectivity test of } \\
\text { these definitions via Inter-Rater } \\
\text { Agreement Information (IRA) } \\
\text { using ADI-R and ADOS tools. }\end{array}$ \\
\hline $\begin{array}{l}\text { De Benedictis, Riccardo; } \\
\text { Umbrico, Alessandro; } \\
\text { Fracasso, Francesca; } \\
\text { Cortellessa, Gabriella; } \\
\text { Orlandini, Andrea; Cesta, } \\
\text { Amedeo (2020) [20] }\end{array}$ & $\begin{array}{l}\text { To create an expert structure } \\
\text { able to provide a variety of } \\
\text { assistive graphs evolving } \\
\text { over time. }\end{array}$ & $\begin{array}{l}\text { Adult patients } \\
\text { (rehabilitation) }\end{array}$ & $\begin{array}{l}\text { AI technologies: } \\
\text { Automated Planning } \\
\text { (AP), Knowledge } \\
\text { Representation and } \\
\text { Reasoning (KR), and } \\
\text { Reinforcement } \\
\text { Learning (RL). }\end{array}$ & $\begin{array}{l}\text { The integration of model-based } \\
\text { and model-free AItechnologies can } \\
\text { contextualize the robot's assistive } \\
\text { behaviors and decide what to do } \\
\text { and how, as well as the } \\
\text { characteristics and needs of the } \\
\text { people assisted. }\end{array}$ \\
\hline $\begin{array}{l}\text { Cooper, Sara; Di Fava, } \\
\text { Alessandro; Vivas, Carlos; } \\
\text { Marchionni, Luca; Ferro, } \\
\text { Francesco (2020) [21] }\end{array}$ & $\begin{array}{l}\text { To review how robots can } \\
\text { assist older adults, people } \\
\text { with mobility problems, } \\
\text { hospital patients, and users } \\
\text { who need healthcare. }\end{array}$ & $\begin{array}{l}\text { Aging population } \\
\text { and users with } \\
\text { multiple chronic } \\
\text { diseases (Review) }\end{array}$ & $\begin{array}{c}\text { Socially Assistive } \\
\text { Robots. }\end{array}$ & $\begin{array}{l}\text { Research has shown that robots } \\
\text { can lower the degree of stress and } \\
\text { anxiety among older people with } \\
\text { dementia, and that they can be } \\
\text { adapted to be telepresence robots. }\end{array}$ \\
\hline $\begin{array}{l}\text { Turja, Tuuli; Parviainen, } \\
\text { Jaana (2020) [22] }\end{array}$ & $\begin{array}{l}\text { To expose and bring attention } \\
\text { to our knowledge of robot } \\
\text { acceptance and, concretely, to } \\
\text { workers' concerns. }\end{array}$ & $\begin{array}{c}\text { Nurses, } \\
\text { Physiotherapists, } \\
\text { Instructors, other } \\
\text { professions }\end{array}$ & PARO and NAO. & $\begin{array}{l}\text { There is a difference in the } \\
\text { acceptance of robots in hospitals } \\
\text { and homes, with this technology } \\
\text { being more accepted in the } \\
\text { workplace. }\end{array}$ \\
\hline $\begin{array}{l}\text { Beane, Matthew, I. (2020) } \\
\text { [23] }\end{array}$ & $\begin{array}{l}\text { To note that robots have not } \\
\text { only a functional and } \\
\text { instrumental value. The } \\
\text { hospital services are enhanced. }\end{array}$ & $\begin{array}{c}\text { Healthcare } \\
\text { Professionals }\end{array}$ & $\begin{array}{c}\text { RP-7 robotic } \\
\text { telepresence system. }\end{array}$ & $\begin{array}{l}\text { There are three outcomes: robots } \\
\text { can add value, such as quality, } \\
\text { status, or enhanced access to } \\
\text { services; a collateral effect of using } \\
\text { robots in hospitals was an increase } \\
\text { in their revenue; marketing, } \\
\text { fundraising, and business } \\
\text { development activities can benefit } \\
\text { from employing robots. }\end{array}$ \\
\hline $\begin{array}{l}\text { Moerman, Clara J.; van } \\
\text { der Heide, Loek; Heerink, } \\
\text { Marcel (2019) [24] }\end{array}$ & $\begin{array}{l}\text { To provide a review to } \\
\text { inventory the use of SAR in } \\
\text { hospitals. }\end{array}$ & Children (Review) & SAR review. & $\begin{array}{l}\text { The findings show that SAR have a } \\
\text { positive impact on a child's } \\
\text { emotional state. }\end{array}$ \\
\hline $\begin{array}{c}\text { Neerincx, Mark A.; van } \\
\text { Vught, Willeke; } \\
\text { Henkemans, Olivier } \\
\text { Blanson; Oleari, Elettra; } \\
\text { Broekens, Joost; Peters, } \\
\text { Rifca; Kaptein, Frank; } \\
\text { Demiris, Yiannis; Kiefer, } \\
\text { Bernd; Fumagalli, Diego; } \\
\text { Bierman, Bert (2019) [25] }\end{array}$ & $\begin{array}{l}\text { To provide a socio-cognitive } \\
\text { engineering (SCE) } \\
\text { methodology. It conducts } \\
\text { research and development } \\
\text { for HRI. }\end{array}$ & Children & $\begin{array}{l}\text { Socio-cognitive } \\
\text { engineering (SCE) } \\
\text { methodology. }\end{array}$ & $\begin{array}{l}\text { Four outcomes appeared (joint } \\
\text { objectives, agreements, experience } \\
\text { sharing, and feedback and } \\
\text { explanation) plus an information } \\
\text { layer base and interaction design } \\
\text { to consider the long-term } \\
\text { regulation of children's diseases. }\end{array}$ \\
\hline
\end{tabular}

Logan, Deirdre E.;

Breazeal, Cynthia;

Goodwin, Matthew S.; Jeong, Sooyeon;

O'Connell, Brianna;

Smith-Freedman, Duncan;

Heathers, James;

Weinstock, Peter (2019) [26]

\begin{tabular}{|c|c|}
\hline $\begin{array}{l}\text { To introduce SR technology to } \\
\text { pediatric patients. }\end{array}$ & Children \\
\hline
\end{tabular}

Joy and agreeable states achieved high levels, better than with other interventions. 
Table 3. Cont.

\begin{tabular}{|c|c|c|c|c|}
\hline Authors & Goals & Population & Concept Origin & Main Outcomes \\
\hline $\begin{array}{c}\text { Melo, Francisco S.; } \\
\text { Sardinha, Alberto; Belo, } \\
\text { David; Couto, Marta; } \\
\text { Faria, Miguel; Farias, } \\
\text { Anabela; Gamboa, Hugo; } \\
\text { Jesus, Cada; Kinarullathil, } \\
\text { Mithun; Lima, Pedro; Luz, } \\
\text { Luis; Mateus, Andre; } \\
\text { Melo, Isabel; Moreno, } \\
\text { Plinio; Osorio, Daniel; } \\
\text { Paiva, Ana; Pimentel, } \\
\text { Jhielson; Rodrigues, Joao; } \\
\text { Sequeira, Pedro; } \\
\text { Solera-Urena, Ruben; } \\
\text { Vasco, Miguel; Veloso, } \\
\text { Manuela; Ventura, } \\
\text { Rodrigo (2019) [27] }\end{array}$ & $\begin{array}{l}\text { To illustrate the INSIDE } \\
\text { system, where mobile robots } \\
\text { are present during therapy for } \\
\text { ASD. }\end{array}$ & Children (ASD) & INSIDE system. & $\begin{array}{l}\text { Wizard of Oz helped to improve } \\
\text { the perception and behavior } \\
\text { modules in social interaction. The } \\
\text { robot was able to be autonomous } \\
\text { in the end. }\end{array}$ \\
\hline $\begin{array}{c}\text { Nguyen Dao Xuan Hai; } \\
\text { Luong Huu Thanh Nam; } \\
\text { Nguyen Truong Thinh) } \\
\text { (2019) [28] }\end{array}$ & $\begin{array}{l}\text { To design and implement a } \\
\text { telepresence robot to allow } \\
\text { communication and } \\
\text { interaction in different } \\
\text { environments. }\end{array}$ & Elderly & $\begin{array}{l}\text { Telepresent robot } \\
\text { design and } \\
\text { development. }\end{array}$ & $\begin{array}{l}\text { Telemedicine provided benefits, } \\
\text { such as communication and } \\
\text { interaction assistance, to elders. }\end{array}$ \\
\hline $\begin{array}{c}\text { Ahn, Ho Seok; Yep, } \\
\text { Wesley; Lim, Jongyoon; } \\
\text { Ahn, Byeong Kyu; } \\
\text { Johanson, Deborah L.; } \\
\text { Hwang, Eui Jun; Lee, Min } \\
\text { Ho; Broadbent, Elizabeth; } \\
\text { MacDonald, Bruce A. } \\
\text { (2019) [29] }\end{array}$ & $\begin{array}{l}\text { To update the receptionist } \\
\text { system robot in a healthcare } \\
\text { setting. HealthBots are } \\
\text { divided into a receptionist } \\
\text { robot, a nurse assistant robot } \\
\text { system, and a server. }\end{array}$ & $\begin{array}{l}\text { University } \\
\text { students } \\
\text { (Healthcare) }\end{array}$ & $\begin{array}{l}\text { EveR4, Nao and } \\
\text { ReceptionBot. }\end{array}$ & $\begin{array}{c}\text { They developed different types of } \\
\text { modules (perception, } \\
\text { decision-making, and reaction } \\
\text { modules) and organized two case } \\
\text { studies to look for basic social } \\
\text { features for receptionist robots in } \\
\text { the hospital. }\end{array}$ \\
\hline $\begin{array}{c}\text { Sequeira, Joao S. (2019) } \\
\text { [30] }\end{array}$ & Development of a social robot. & Children & $\begin{array}{l}\text { Child interaction with } \\
\text { an mbot. }\end{array}$ & Implement humanistic knowledge. \\
\hline $\begin{array}{l}\text { Meghdari, Ali; Shariati, } \\
\text { Azadeh; Alemi, Minoo; } \\
\text { Nobaveh, Ali } \\
\text { Amoozandeh; Khamooshi, } \\
\text { Mobin; Mozaffari, Behrad } \\
\text { (2018) [31] }\end{array}$ & $\begin{array}{c}\text { To design and develop a } \\
\text { mobile social robot companion } \\
\text { for use by children with cancer } \\
\text { during healthcare. }\end{array}$ & $\begin{array}{c}\text { Hospitalized } \\
\text { Children (cancer) }\end{array}$ & Design of social robots & $\begin{array}{l}\text { Design and construction phases of } \\
\text { a social robot and its specifications } \\
\text { (mechanical, electronics, and } \\
\text { control aspects of the robot). }\end{array}$ \\
\hline $\begin{array}{c}\text { Valles-Peris, Nuria; } \\
\text { Angulo, Cecilio; } \\
\text { Domenech, Miquel (2018) } \\
\text { [32] }\end{array}$ & $\begin{array}{l}\text { To analyze children's thoughts } \\
\text { of Human-Robots Interaction } \\
\text { in social robot environments in } \\
\text { hospitals, taking into account } \\
\text { ethical and social values when } \\
\text { designing a SAR. }\end{array}$ & $\begin{array}{l}\text { Hospitalized } \\
\text { children }\end{array}$ & $\begin{array}{l}\text { HRI- Child-Robot } \\
\text { Interactions. }\end{array}$ & $\begin{array}{c}\text { Potential of studying the } \\
\text { imaginaries of HRI, and it } \\
\text { concludes that their integration in } \\
\text { the final design of robots provides } \\
\text { a way to incorporate ethical } \\
\text { values. }\end{array}$ \\
\hline $\begin{array}{l}\text { Burns, Rachael; Jeon, } \\
\text { Myounghoon; Park, } \\
\text { Chung Hyuk (2018) [33] }\end{array}$ & $\begin{array}{l}\text { To provide a framework to } \\
\text { improve human-robot } \\
\text { interaction through robotic } \\
\text { imitation of users' gestures. }\end{array}$ & $\begin{array}{l}\text { University } \\
\text { Students } \\
\text { (addressed to } \\
\text { children with } \\
\text { autism) }\end{array}$ & Imitation in Robots. & $\begin{array}{c}\text { A humanoid robotic agent } \\
\text { fraternizes with and plays games } \\
\text { with a user. Subjects exhibited } \\
\text { positive emotional states, better } \\
\text { mood contagion instances towards } \\
\text { the robot, and improved } \\
\text { autonomy. }\end{array}$ \\
\hline $\begin{array}{l}\text { Chen, Chaona; Garrod, } \\
\text { Oliver G. B.; Zhan, Jiayu; } \\
\text { Beskow, Jonas; Schyns, } \\
\text { Philippe G.; Jack, Rachael } \\
\text { E. (2018) [34] }\end{array}$ & $\begin{array}{c}\text { To reverse engineer } \\
\text { psychologically valid facial } \\
\text { expressions of emotion into } \\
\text { SAR. }\end{array}$ & $\begin{array}{l}\text { Not applicable } \\
\text { (technical paper) }\end{array}$ & Reverse engineering. & $\begin{array}{l}\text { Reverse engineer methodologies } \\
\text { updated for flexible facial } \\
\text { expressions into a social robot } \\
\text { head. Benefits of taking into } \\
\text { account human users to derive } \\
\text { facial expressions for SARs. } \\
\text { Psychology is a relevant discipline } \\
\text { in designing social robots. }\end{array}$ \\
\hline
\end{tabular}


Table 3. Cont.

\begin{tabular}{cccc}
\hline Authors & Goals & Population & Concept Origin \\
\hline & & & \\
& & Nurses, & Assistive humanoid \\
Papadopoulos, Irena; & To observe hospital staff's uses & Healthcare, & utilizations and \\
of SARs in the health and & Professionals, & animal-like robots in \\
Koulouglioti, Christina; & social care sector. & Social Care & the health and social \\
Ali, Sheila (2018) [35] & workers (Review) & care sector.
\end{tabular}

To capture people's images and social media content for social activities and/or health monitoring use. Image capturing processes were optimized using a visual servo. Lee, Woo Ho (2018) [36]

Dodds, Penny; Martyn, Katharine; Brown, Mary (2018) [37]
To prevent and avoid infection, prevention control standards.
Elderly

Social robotics-Navigation.
Autonously capture users images and feed pictures and live-motion clips to social media or hospitals for health monitoring

Hospital staff expressed mixed views regarding the use of robots in a healthcare context. They mainly thought of the challenge that robots may pose to patients and not to themselves. They included a tasks list for the robots; they bore in mind ethical values, such as safety or privacy.

$$
\text { purposes. }
$$


Table 3. Cont.

\begin{tabular}{|c|c|c|c|c|}
\hline Authors & Goals & Population & Concept Origin & Main Outcomes \\
\hline $\begin{array}{l}\text { Goncalves, David; } \\
\text { Arsenio, Artur (2015) [43] }\end{array}$ & $\begin{array}{l}\text { This paper describes the } \\
\text { construction, design, and early } \\
\text { development process of an } \\
\text { external structure for several } \\
\text { MoNARCH mobile robots } \\
\text { used in a healthcare context. }\end{array}$ & $\begin{array}{c}\text { Children (specific } \\
\text { needs). }\end{array}$ & $\begin{array}{l}\text { YDR for conceiving } \\
\text { the Monarch fleet of } \\
\text { mobile, cognitive } \\
\text { robots. }\end{array}$ & $\begin{array}{l}\text { 1. What to do and what to avoid in } \\
\text { robot design } 2 \text {. Multidisciplinary } \\
\text { approach using functional and } \\
\text { aesthetic features and economic } \\
\text { factors combined with human } \\
\text { factors. }\end{array}$ \\
\hline $\begin{array}{l}\text { Nergui, Myagmarbayar; } \\
\text { Komekine, Keisuke; } \\
\text { Nagai, Hiroki; Otake, } \\
\text { Mihoko (2015) [44] }\end{array}$ & $\begin{array}{l}\text { To ascertain correct motions in } \\
\text { the laughter of robots based on } \\
\text { human motions. To have a } \\
\text { robot recognize a face, facial } \\
\text { expression, speech (synthesis } \\
\text { and some contents) to assist } \\
\text { and influence older people in } \\
\text { dialogues. }\end{array}$ & $\begin{array}{l}\text { Young people } \\
\text { (addressed to } \\
\text { older people) }\end{array}$ & $\begin{array}{l}\text { Conversational robot } \\
\text { to support the } \\
\text { rehabilitation of } \\
\text { patients with } \\
\text { dementia. }\end{array}$ & $\begin{array}{l}\text { The sounds "fu-fu-fu" and } \\
\text { "ha-ha-ha" coming from the robot } \\
\text { were achieved using hand } \\
\text { movements just in front of the } \\
\text { mouth; meanwhile, another sound, } \\
\text { "wa-ha-ha-ha", was produced } \\
\text { when the hand's robots were } \\
\text { moved. }\end{array}$ \\
\hline $\begin{array}{l}\text { Ferreira, Isabel; Sequeira, } \\
\text { Joao (2014) }[45]\end{array}$ & $\begin{array}{l}\text { To provide the MOnarCH } \\
\text { Project with a fleet of } \\
\text { networked robots (NRS) with } \\
\text { cognitive skills to define the } \\
\text { interaction context. }\end{array}$ & Children & $\begin{array}{l}\text { Interactions between } \\
\text { robots with children } \\
\text { to improve quality } \\
\text { of life. }\end{array}$ & $\begin{array}{l}\text { The MOnarCH mission project's } \\
\text { explanatory conclusions reveal an } \\
\text { improvement in the quality of life } \\
\text { of hospitalized children. The } \\
\text { robots, by interacting with } \\
\text { children in a hospital, keep them } \\
\text { involved in socially exciting } \\
\text { activities, play with them, and play } \\
\text { the role of assisting schoolteachers. }\end{array}$ \\
\hline $\begin{array}{c}\text { Van Wynsberghe, Aimee } \\
\text { (2013) [46] }\end{array}$ & $\begin{array}{l}\text { To integrate ethics into robot } \\
\text { development in healthcare, } \\
\text { and illustrate it using } \\
\text { an example. }\end{array}$ & Children (cancer) & $\begin{array}{c}\text { CCVSD } \\
\text { (Care-Centered } \\
\text { Value-Sensitive } \\
\text { Design) approach. }\end{array}$ & $\begin{array}{l}\text { A "wee-bot" robot was used in } \\
\text { urine tests with pediatric oncology } \\
\text { patients following CCVSD. The } \\
\text { requirements that need ethical } \\
\text { consideration and the protocol to } \\
\text { follow were integrated into this } \\
\text { approach using different } \\
\text { prototypes. }\end{array}$ \\
\hline
\end{tabular}

The clarity of interpretation is considered an advantage; however believability and engagement can be negatively affected by continuous repetitions.

Lewis, Matthew; $\quad$ To develop an interacting SAR Canamero, Lola (2013) [47] in order to help hospitalized children.
Professional

dancer, actor

Coached (by a director)
Social expressive human-robot interaction.

Micro-expressions that are so rich in real life are not achieved by the robot and affect the children's interaction.

A different approach from the classical bottom-up

To provide an approach to design social spaces for assistant robots with easy

Elara, Mohan Rajesh Rojas, Nicolas; Seah, Sue; Sosa, Ricardo (2013) [48] actions that enable robots to trespass their boundaries and achieve their

planned missions.

$\begin{array}{cc}\text { Singapore } & \text { Robot for service and } \\ \text { hospital } & \text { human-robot } \\ \text { community } & \text { interaction. }\end{array}$

characterization. Five guidelines are suggested: observability, accessibility, manipulability, activity, and safety to assist the outstanding autonomous robotic systems in indoor and outdoor places.

Acceptance, Benefits, and Concerns are discussed: Social norms influence the design (it is difficult to refuse a call if you can see the interlocutor). Older adults prefer the mouse over a graphical user interface.

Robo-Ethics is a guide for involving robots in medicine. Even for the university curriculum and bio-engineering fields. 
Table 3. Cont.

\begin{tabular}{|c|c|c|c|c|}
\hline Authors & Goals & Population & Concept Origin & Main Outcomes \\
\hline $\begin{array}{l}\text { Goris, Kristof; Saldien, } \\
\text { Jelle; Vanderniepen, Innes; } \\
\text { Lefeber, Dirk (2009) [50] }\end{array}$ & $\begin{array}{l}\text { To provide background } \\
\text { information on the Probo } \\
\text { robot and present } \\
\text { experimental results for a } \\
\text { robot head prototype that } \\
\text { exhibits facial expressions. }\end{array}$ & Children & $\begin{array}{c}\text { The huggable robot } \\
\text { Probo. }\end{array}$ & $\begin{array}{l}\text { A robot with an actuated head that } \\
\text { can be hugged and characterized } \\
\text { by an animal shows expressions. It } \\
\text { provides engagement using } \\
\text { an interface. }\end{array}$ \\
\hline
\end{tabular}

Table 4. Research question 2 (RQ2) on the uses and applications of social robots.

\begin{tabular}{|c|c|c|c|c|}
\hline Authors & Goals & Population & Concept Origin & Main Outcomes \\
\hline $\begin{array}{l}\text { Sutherland, Craig J.; Ahn, } \\
\text { Byeong Kyu; Brown, } \\
\text { Bianca; Lim, Jongyoon; } \\
\text { Johanson, Deborah L.; } \\
\text { Broadbent, Elizabeth; } \\
\text { MacDonald, Bruce A.; } \\
\text { Ahn, Ho Seok (2019) [51] }\end{array}$ & $\begin{array}{l}\text { To study people's perception } \\
\text { of a medical receptionist robot. }\end{array}$ & University & Friendliness of robots. & $\begin{array}{l}\text { A robot can be a friendly } \\
\text { receptionist. }\end{array}$ \\
\hline $\begin{array}{c}\text { van der Putte, Daisy; } \\
\text { Boumans, Roel; Neerincx, } \\
\text { Mark; Rikkert, Marcel } \\
\text { Olde; de Mul, Marleen } \\
\text { (2019) [52] }\end{array}$ & $\begin{array}{l}\text { Investigate the ability of a } \\
\text { social robot to autonomously } \\
\text { take over the administration of } \\
\text { a questionnaire. }\end{array}$ & $\begin{array}{l}\text { Adult } \\
\text { patientsNurses }\end{array}$ & $\begin{array}{l}\text { Autonomous } \\
\text { administration of } \\
\text { questionnaires. }\end{array}$ & $\begin{array}{l}\text { One could imagine scenarios in } \\
\text { which the robot saves time on } \\
\text { routine tasks with automatic } \\
\text { storage in the patients' electronic } \\
\text { medical records. There is a concern } \\
\text { about using the robot at the } \\
\text { expense of direct personal } \\
\text { patient care. }\end{array}$ \\
\hline $\begin{array}{c}\text { Sarabia, Miguel; Young, } \\
\text { Noel; Canavan, Kelly; } \\
\text { Edginton, Trudi; Demiris, } \\
\text { Yiannis; Vizcaychipi, } \\
\text { Marcela P. (2018) [53] }\end{array}$ & $\begin{array}{l}\text { To verify whether adult } \\
\text { patients are happy interacting } \\
\text { with social robots while } \\
\text { hospitalized. }\end{array}$ & $\begin{array}{l}\text { Adult patients } \\
\text { (some with } \\
\text { dementia) }\end{array}$ & $\begin{array}{l}\text { Combating social } \\
\text { isolation in hospitals } \\
\text { with assistive robots. }\end{array}$ & $\begin{array}{l}\text { Patients in the hospital enjoy } \\
\text { socializing with robots. }\end{array}$ \\
\hline
\end{tabular}

Meghdari, Ali; Shariati, Azadeh; Alemi, Minoo; Vossoughi, Gholamreza R.; Eydi, Abdollah; Ahmadi, Ehsan; Mozafari, Behrad; Nobaveh, Ali

Amoozandeh; Tahami, Reza (2018) [54]

Eriksson, Yvonne (2018) [55]
To assess children's acceptance, feelings, and involvement with the robot and determine how much the robot resembled the sketch.

$\begin{array}{cc}\begin{array}{c}\text { Child patients } \\ \text { (cancer) }\end{array} & \begin{array}{c}\text { Designing social } \\ \text { robots as a } \\ \text { companion. }\end{array}\end{array}$

Child patients companion.
Pediatric patients with cancer engage with and are interested in this robot.
To understand how the design (from appearance and socio-cultural aspects) of the robots influence older people, their relatives, caregivers, and decision-makers.
Elderly Robot perception. historical culture and media on both the perceptions and experiences of aging. The relations of the perceptions and experiences to the acceptance (or not) of robots as tools for nursing older adults.

Health and social care workers reported mixed views regarding the use of robots in a healthcare setting. The impact that robots have on patients related to safety and privacy.

The interaction must meet the needs of specific end-user groups. The perceived utility of a robot is very much tied to its tasks and proper functioning.The social acceptance was ambivalent.

There was a significant reduction in caregiver burden.A concern was raised about the need for specific training of caregivers. 
Table 4. Cont.

\begin{tabular}{|c|c|c|c|c|}
\hline Authors & Goals & Population & Concept Origin & Main Outcomes \\
\hline $\begin{array}{l}\text { Jeong, Sooyeon; Breazeal, } \\
\text { Cynthia; Logan, Deirdre; } \\
\text { Weinstock, Peter (2018) } \\
\text { [59] }\end{array}$ & $\begin{array}{l}\text { To investigate how different } \\
\text { interventions affect physical } \\
\text { activity and social engagement } \\
\text { in child patients. }\end{array}$ & Child patients & $\begin{array}{c}\text { Interventions for } \\
\text { pediatric care in child } \\
\text { life program. }\end{array}$ & $\begin{array}{l}\text { The children interacted longer and } \\
\text { talked more when given a social } \\
\text { robot than when given a virtual } \\
\text { character or a plush toy. The } \\
\text { family members, co-present but } \\
\text { not directly engaged in the } \\
\text { interaction during an intervention, } \\
\text { were more likely to interact. A } \\
\text { social robot could have a } \\
\text { significant socio-emotional impact } \\
\text { on children's hospitalization } \\
\text { engagement, wellbeing, and } \\
\text { general hospital experience. }\end{array}$ \\
\hline
\end{tabular}

Meghdari, Ali; Alemi, Minoo; Khamooshi,

Mobin; Amoozandeh, Ali;

Shariati, Azadeh;

Mozafari, Behrad (2016) [60]
To demonstrate the conceptual design features of a mobile social robot ("Dr. Arash") for edutainment and therapeutic interventions in hospitalized children.
Children (cancer)Psychologists
Quality of life during

the treatment process.

The design of robots (mobile social robot) intended to meet the needs of the population in question needs to consider: 1/ design

factors, dimensions, and degrees of freedom, movement system, actuators and sensors, the physical appearance of the robot, design of the head, design of the face, communication modules.

\begin{tabular}{cc}
$\begin{array}{c}\text { Sequeira, Joao Silva; } \\
\text { Ferreira, Isabel Aldinhas } \\
\text { (2016) [61] }\end{array}$ & $\begin{array}{c}\text { To assess the relationships that } \\
\text { are established between } \\
\text { humans and MOnarCH robots } \\
\text { in a social environment. }\end{array}$ \\
\hline $\begin{array}{c}\text { Diaz-Boladeras, Marta; } \\
\text { Angulo, Cecilio; }\end{array}$ & $\begin{array}{c}\text { To provide smart company to } \\
\text { alleviate feelings of anxiety, } \\
\text { loneliness, and stress in } \\
\text { Domenech, Miquel; } \\
\text { Albo-Canals, Jordi; }\end{array}$ \\
$\begin{array}{c}\text { Serrallonga, Nria; Raya, } \\
\text { Cristobal; Barco, Alex } \\
\text { (2016) [62] }\end{array}$ & companions.
\end{tabular}

$\begin{array}{cc}\begin{array}{c}\text { ChildrenAdults } \\ \text { team members, }\end{array} & \begin{array}{c}\text { Integration of the } \\ \text { robot in a specific } \\ \text { parents, and }\end{array} \\ \text { social environment. }\end{array}$

MOnarCH social robots may play a highly positive role in socially difficult environments.

Robotic pets had the effect of mediating and facilitating interaction and relationships between the different agents involved in the care process. The robot took on different roles: as a distractor, as a featured toy, as a companion.

The patients were primarily positive and accepting of the robot, acknowledging its benefits as a companion: reduced medical care utilization, increased quality of life, increased adherence, and companionship.More familiar games may be more accessible for older people to relate to and increase user confidence.It is feasible to use assistive healthcare robots in homes in this population.

MacDonald, Bruce A.

Ahn, Ho Seok; Peri,

Kathryn; Broadbent,

Elizabeth (2015) [63]

usefulness of robots in managing the medication of older patients living alone.
Older

adults/Elderly

conditions)
Medical care, utilization, quality of life, adherence, and robot acceptance.
Alemi, Minoo; Meghdari, Ali; Ghanbarzadeh, Ashkan; Moghadam, Leila Jafari; Ghanbarzadeh Anooshe (2014) [64]
To propose a new approach that considers the effect of a humanoid robot as a therapy assistant in treating pediatric distress.

\section{Children (Cancer)}

Humanoid robot with different communication abilities.

A humanoid robot can be beneficial: by elevating the efficacy of interventions, encouraging kids to be more interactive, and it can be significantly helpful in teaching them their afflictions, instructing them on methods to confront their distress themselves and take control of their situation.

\footnotetext{
Alemi, Minoo; Meghdari, Ali; Ghanbarzadeh,

Ashkan; Moghadam, Leila

Jafari; Ghanbarzadeh,

Anooshe (2014) [65]
}

To explore the impact of humanoid robots as a therapy assistant to deal with distress in child patients.
Feasibility of using social robots in psychological interventions for anger, anxiety, and depression in pediatric cancer. 
Table 4. Cont.

\begin{tabular}{|c|c|c|c|}
\hline Authors & Goals & Population & Concept Origin \\
\hline $\begin{array}{c}\text { Robinson, Hayley; } \\
\text { MacDonald, Bruce; Kerse, } \\
\text { Ngaire; Broadbent, } \\
\text { Elizabeth (2013) [66] }\end{array}$ & $\begin{array}{l}\text { To investigate the psychosocial } \\
\text { effects of the companion robot } \\
\text { to improve the quality of life, } \\
\text { mood, and loneliness in } \\
\text { elderly residents. }\end{array}$ & $\begin{array}{c}\text { Older } \\
\text { adults/Elderly } \\
\text { (nursing home } \\
\text { patients) }\end{array}$ & $\begin{array}{l}\text { Robot to improve care } \\
\text { (psychosocial effects). }\end{array}$ \\
\hline
\end{tabular}

Bartlett, Madeleine E.; Costescu, Cristina; Baxter, Paul; Thill, Serge (2020) [19]
To characterize the problems that a social robot faces in the real world when automating an Autism Spectrum Disorder (ASD) diagnosis.
Children (ASD) Social robot in the real world.

\section{Main Outcomes}

The use of the seal robot was effective, with users exhibiting

lower loneliness scores from

baseline to follow-up compared to a control group.

1. It is feasible to incorporate technology-based means into the ASD diagnostic process. 2. Social robotics is explored in relation to technological issues (mostly solved) and understanding human-robot interactions from the

Wizard of Oz studies (yet to be solved).

Boumans, Roel; van Meulen, Fokke; Hindriks,

Koen; Neerincx, Mark;
To design a multimodal dialogue for a social robot to acquire PROMs for older patients.$$
\text { patients. }
$$

Pepper robot from Softbank Robotics.
Elderly

$$
\text { (2020) [67] }
$$

The effectiveness, efficiency, and usability perceived by older adults of acquiring PROMs from a social robot was positive, favorable, and appreciated.
Hung, Lillian; Gregorio,

Mario; Mann, Jim;

Wallsworth, Christine;

Horne, Neil; Berndt,

Annette; Liu, Cindy (2019) [68]
To analyze perceptions of experiences with PARO robots in a hospital setting.
Older people/Elderly (Dementia)
Human-robot and human-human interactions in a hospital.

The robot helps people with dementia maintain a sense of self in the world (friend), the baby seal

facilitates social connection

(conversation), and the robot transforms and humanizes the clinical environment (happiness).

Patients saw a benefit in maintaining a connection with their siblings and the retention of their role in the family. The contact

To evaluate the perceived benefits and difficulties encountered by users and their families (family dynamics).
Children, (Diabetes)Families (parents, siblings)Nursing staff
Benefits of telepresence robots.

Barland, Jean-Christophe; Blay, Jean-Yves;

Marec-Berard, Perrine (2020) [69]

\section{Jurdi, Sandra; Montaner,} Jorge; Garcia-Sanjuan, Fernando; Jaen, Javier; Nacher, Vicente (2018) [70]
To analyze existing approaches in order to identify gaps for future research.
Child patients (Review)
Game Technologies. with their child reassured parents.

The nursing staff's professional relationship with the children was enhanced and they interacted with the children's extended family.

Social robots as game technologies present physical and psychological benefits to hospitalized children.

They motivate children in physical rehabilitation and different medical procedures.

\section{Ali, Sara; Samad}

Mohammad; Mehmood,

Faisal; Ayaz, Yasar; Qazi, Wajahat Mehmood; Khan,

Muhammad Jawad; Asgher, Umer (2020) [71]
To control NAO robot with an interface developed using the MyoArmband sensor.
NAO and MyoArmband Adults targeted for patients with severe medical conditions
Interface in progress and as a future framework for robots targeted for users with severe medical conditions who cannot

communicate using normal communication channels with the robot.

Hung, Lillian; Liu, Cindy;

Woldum, Evan; Au-Yeung,

Andy; Berndt, Annette;

Wallsworth, Christine;

Horne, Neil; Gregorio, Mario; Mann, Jim;

Chaudhury, Habib (2019)

$$
\text { [72] }
$$

To find key benefits and barriers using PARO.
Older people with Benefits and barriers dementia
The key benefits identified were: decreased negative emotions and behavioral symptoms, as well as enhanced social engagement.

Thus, mood and quality of experience augmented. The same

happened with patients with anxiety and depression.
Kobayashi, Toru; Sameshima, Naohiro; Imai,

Tetsuo; Arai, Kenichi;

Watanabe, Tomoki;

Miyazaki, Teiichiro;

Tsujino, Akira (2019) [73]
To have a complete operational robot for the elderly with dementia, an artificial intelligence diagnosis tool was added, which provides a conversational diagnosis method.
Conversational diagnosis method integrated in a robot for the elderly with dementia.
Messages can be sent using the

LINE app that the robot can
Elderly
(dementia) execute. 


\section{Discussion}

We have found in the literature numerous terms related to social robots such as (1) chatbot, (2) bot, (3) virtual assistant, (4) robot companion, (5) artificial social, intelligent machine, (6) social assistive robots, (7) telepresence robot, (8) remotely operated robot, (9) personal assistant, and (10) autonomous robot. In a way, all of them fall within our scope; the difference among them comes from the fact that some of them combine software and hardware (4-10), while others are usually only software (1-3). [43,60] offer exhaustive and historical reviews of robots. Specifically, in a healthcare context, we found that the most accurate definition is related to the central care concept. Thus, a social robot aims to serve a person in a caring interaction rather than perform a mechanical task [16], and it usually has hardware and software components.

As if this were not enough, there are also other associated terms that are commonly used that range from small, handheld devices like smartphones, to thermostats and pet-like robots, such as Paro or MiRo, all the way to life-sized humanoid robots, such as Nadine or Moxie. This suggests that this undertaking represents a highly variable space [15]. This article provides a technology classification: objects (i.e., a chair), tools (i.e., hammer), machines (i.e., coffee machines), artificially intelligent machines (i.e., smartphone), and artificially socially intelligent machines (i.e., Paro). Our target is the last of these, and sometimes semantics are involved, as we saw in the first paragraph. A series of dimensions is proposed in [15] to describe all of them in more detail: Prior experience/expectations, Automated functionality, Functional Repertoire, Form-function mapping, Size, Human-like form or motion, Socialness, and Intelligence.

When technology is a means to an end, some adaptations involving Lego are used [74] in the robotics program. Cloud computing technology is present too; Google and Microsoft have released chatbot health-platform services that are usable in everyday life [75].

The control of one's actions and their consequences, or the sense of control, is called a sense of agency (SoA). Cozmo robots and Cozmo cubes reduce it, and in return, show that reduced SoA is not observed in the presence of a passive non-agent device [76].

In this work, we focused on the healthcare context. However, there are other reviews in other contexts, such as urban spaces and in artificially socially intelligent machines called social robots [47]. Next, we are going to discuss designing and interacting with social robots in healthcare contexts.

$R Q 1$. How are social robots designed? Are they ethically designed?

The development of social robots includes several algorithms as well as different implementations, such as face recognition, speech recognition, cognitive and decisionmaking modules [29,39,40,42,44,60,61,66], emotional modules [47,50], and ergonomics [43], which must also be considered fundamental. Achieving new levels of conversational modeling and knowledge and providing intelligent interactive platforms that can interact with users is a promising field [75].

We found that $75 \%$ of HRI studies are laboratory-based [15], mainly intended to study certain aspects, such as prior experience/expectations, automated functionality, functional repertoire, form-function mapping, size, human-like form or motion, socialness, intelligence, and other bases for the development of robotic technology [34]. However, long-term interaction is a challenge for socially assistive and educational robots [23], and HRI research can be improved by studying the contexts [25].

Considerable research is being conducted in this regard to improve the navigation of social robots $[27,28,30,48,61]$ in spaces where they must coexist with humans in accordance with subtle cultural rules [17] and taking into account certain disabilities, such as hearing impairment [77]. In [17], a model is proposed for the motion of a robot inside a hospital environment. Moreover, as a result of the COVID-19 pandemic, social interaction is restricted, and a minimum distance between robots and humans should be respected.

Regarding the appearance of robots or the features of robots intended for use by children or the elderly, pet-like SAR, like dinosaurs or animals (Pleo, Paro, Parrot, Aibo, Huggable, or iCat) are preferred $[18,21,26,34,38]$. People can also interpret affective non- 
verbal behavior in robots [21]. A stress-reducing effect on people who are ill in childhood and old age has been identified [24,62]. As concerns human-like robots, NAO is one of the most accepted robots in healthcare [65]. In [16] found the main concern with social robots to be their cultural acceptance and skills. Additionally, feminine robots are preferred by users. Another concern found in this study was to understand what the human is doing; however, the robot's appearance depends on its application, the user's age, and several other factors $[33,60,61]$.

As a method for designing and implementing AAL facilities, the person-centered process has been found to be the best design methodology, as it allows for conversations between participants and healthcare professionals [78]. However, [19] found that highly developed algorithms were needed to integrate more general cognitive aspects in the robot to enable it to diagnose certain illnesses, such as ASD. Another methodology that is useful in healthcare contexts (children with diabetes) is Socio-Cognitive Engineering (SCE) [25], as it enables the integration of different theories, models, and visions of patients and caregivers. More ingredients can be added to the interaction, such as prediction and feedback. Such is the case when using NAO in heart disease settings, which offers users a new way to understand the meaning of their vital signs through human-robot interaction [79].

Although social robots can promote fundamental values of care (i.e., patient safety, dignity, and wellbeing [22,32]), some researchers believe that doing experiments to test social robots with child patients is not ethical [80]. Besides, care services are highly regulated, and special legislation is required for care-work robotics [22].

According to the International Federation of Robotics (IFR), there is a framework of components of ethical importance, the CCVSD (Care-Centered Value-Sensitive Design) approach [46]. It consists of a framework of components of ethical importance that provides a list of components to take into consideration when evaluating a care robot: the use context, the care practice, the actors involved, the type of care robot (its capabilities, appearance, etc.) and the list of values involved for the practice in question in the stated context (i.e., the interpretation and prioritization of care values) [46].

We found some ethical principles applied to the design of social robot applications in healthcare, such as autonomy, beneficence, non-maleficence, fidelity, justice, utility, and independence [78]. The same authors noted certain ethical requirements in artificial intelligence algorithms for AAL and social robots, like (1) human agency, (2) robustness, (3) privacy, (4) transparency, (5) non-discrimination, (6) wellbeing, and (7) accountability to account for the negative impacts of the systems. Some social robots must comply with the three fundamental guidelines of the Policy Department for Economic, Scientific, and Quality of Life Policies (IPOL) (i) Hospitality and inclusiveness, (ii) Comprehension of individual needs, and (iii) Non-intrusiveness [65]. The ethical dilemma must reconcile the technical problems with patients' needs and rights, with health care services and hospital facilities, in keeping with the ethics in robotics used in medicine [11]. Ethical concerns in the design and use of social robots have been raised involving privacy, restraint, deception, accountability, and psychological damage [45].

Safety — both physical safety and psychological safety $[16,17,43]$ —is another principle considered when designing social robots for healthcare. Security issues such as privacy violations and privacy protection for individuals have been considered in the design $[47,65,81]$.

$R Q 2$. What are the main uses and applications of social robots in healthcare?

Social robots can help with the global problem of the shortage of specialized medical personnel by doing several tasks [82], but their implementation in hospitals must be carried out conscientiously [23]. Robots have been used to quantify significant harm levels in autistic children, by professional caregivers of the elderly, to accompany the elderly while walking, to help persons with motor impairment (i.e., quadriplegia), to monitor and correct during rehabilitation for head, neck, and back pain [16,36], and as a mediator in the interaction with the physician or nurse who performed the treatment [18]. Additionally, social robots can be rehabilitation therapists at home [20] or do administrative tasks, 
such as reception $[29,51]$ in hospitals $[22,60]$. They have also been used for edutainment purposes $[30,70,80]$. Moreover, robots can remind people to take medications, they offer entertainment and memory games, and can be used for videoconferencing [63]. They can be used remotely, connecting the hospital and a patient's home $[28,69,70]$. Moreover, robots have been used to administer automatic questionnaires [52].

During the pandemic, social robots were employed for various purposes, such as the use of drones to enforce quarantine restrictions, alerting individuals to return to their homes, delivering medicine to patients with Covid-19 in Wuhan, and transferring test samples or helping with hospital admissions $[6,8,10]$. Additionally, mobile robots have been used for hospital logistics by sterilizing surfaces with UV light. Robots have been used to take temperature automatically using a thermal sensor. Social robots have reduced the loneliness of people and improved their mental health $[8,83]$.

In healthcare specifically, care workers reject the use of social robots due to their perceptions of their applications, which poses a challenge to the effective implementation of social robots in hospitals [22].

There are two groups where applications that rely on social robots are more widespread within the healthcare environment, namely the elderly and children.

\section{(a) Elderly}

The elderly can benefit from these assistive technologies. In [84], the researchers classify them as ICT (Information and Communication Technologies), Robotics, Telemedicine, Sensor Technology, Video games, and medication dispensing devices. They found that the studies targeted eight problems involving older adults: (1) dependent living (R), (2) fall risk, (3) chronic disease, (4) dementia, (5) social isolation (R), (6) depression (R), (7) poor wellbeing, and (8) poor medication management. (1), (5), and (6) were managed with help from social robots. Social robots have also been used for dementia rehabilitation in hospitals $[37,41,44]$. Robots have been used to improve quality of life and mood in the elderly, while reducing their loneliness [66].

Emotions are connected to social interactions [55]; this is the case for the elderly and (4) dementia patients $[53,56]$. It is a promising field for the PARO robot [68] and exhibits both benefits and barriers [71]. PARO can support the psychosocial needs of the elderly related to inclusion, identity, attachment, occupation, and comfort [68]. When it comes to expressing emotion and inducing empathy, ARI employs a few body cues simultaneously, mainly: facial displays, body movement, posture, and vocal cues [21]. AIBO, PARO, AIBO, and iCat are considered SAR (Social Assistive Robot and Companion). Six thousand, four hundred assisting robots were sold worldwide in health care contexts in 2017. The challenge is to clarify the role of robots in health care and regulate the services they provide through norms and codes of ethics [22].

Hospital personnel must take on arduous tasks that are often repetitive and burdensome, for which they do not have enough time. Here, social robots like Pepper also seem to have a chance to prove their usefulness with questionnaires [67].

Conditioning our home environments influences our wellbeing. They are a critical characteristic in the most vulnerable groups, as in the elderly, who routinely need health care assistance. For example, a virtual assistant and empathic coaches assisted older adults living independently at their homes [78].

For the elderly, robots are not just machines; they offer emotional support, much like a friend and companion who communicates and coexists [81].

\section{(b) Children}

Children are the other vulnerable group where social robots are most applied, specifically with children suffering from diseases such as cancer [54,64]. Such is the case of ARASH [60]. Project MOnarCH (MOnarCH (Multi-Robot Cognitive Systems Operating in Hospitals) is a well-documented European FP7 project for edutainment activities in the pediatric ward of an oncological hospital $[30,43,45,61]$. Robots can improve the quality of 
life of children by interacting with them in hospitals through social and play dynamics, and as school teaching assistants $[18,45,50]$.

In long periods of isolation, telepresence is a practical tool, as we saw in the first section [69], to treat pediatric cancers [31]. Additionally, for long-term relationships and bonding, PLEO is used in the caring system [62], where the child's wellbeing is a priority. Because of its appearance, reminiscent of dinosaurs or an electronic toy, children found PLEO appealing [18]. Stress is a characteristic that is unfortunately also present during long periods of convalescence; interactive stuffed animals can positively influence a child's mood and improve their quality of life during hospitalization. They also provide support when confronting a disease and can serve as a distraction during a medical procedure [24]. Moreover, pain and isolation, along with stress, can be addressed with a table-based avatar and its interactive social robot teddy bear [26]. Positive effects in children were noted using social robots, such as positive mood, engagement, trust, less stress or pain, more relaxation, smiling and openness, better communication, or emotional bonds with users $[24,38,85]$.

The topic of automatic diagnoses can be found in the literature. It is applied in ASD (Autism Spectrum Disorder), where predicting the outcome of actions remains a challenge $[16,27]$. Understanding internal mental states is not the same as observing kinematics [19]. Observable actions include completing a puzzle or finding a given number of balls hidden around a room [27].

The "in the wild" concept is normally used to describe real conditions. Many activities are performed in laboratory conditions or controlled environments, which are not realistic at all. Some works, such as those involving children with diabetes, address it with a methodology for a human-robot partnership framework for prolonged care [25]. For example, the Pleo robot, a baby dinosaur robotic pet, works differently to assist children during hospitalization [38].

Other social robots were used for storing therapy treatments in the database, observing and evaluating therapy processes, or testing urine in children with cancer $[54,64,86]$.

Future work needs to address the problems identified in the current research on the use of social robots by carrying out studies with larger sample sizes, with different populations in different contexts and situations, and with different physical and cognitive skills [66].

\section{Conclusions}

This paper analyzed the state-of-the-art concerning social robots in hospitals, focusing on healthcare contexts, and using WoS and PUBMED as the principal sources of data. As the principal outcomes of this systematic study, we note the following:

- The interest in the use and real application of social robots in hospitals are relatively new: we observed that publications about this topic have increased from 2011. Although the review began in previous years, it was in 2011 when articles that met the inclusion criteria for this review began to appear with more frequency. Therefore, a growing interest in the use of assistive robots in the hospital setting can be observed from that year onwards.

- There is still no academic consensus around the term "social robots".

- There are two central populations where social robots have been applied: children and the elderly.

- Despite the principal potential users (children and elderly) of social robots, some applications for diseases appear in the literature: dementia, cancer, diabetes, and ASD.

- The bibliometric study shows no consolidated research community around social robots in hospitals or for healthcare. Establishing a consolidated discipline around these topics would require an extensive collaboration network.

- There are many benefits to using social robots in healthcare contexts, such as in mental health, where robots promote a positive mood, engagement, trust, less stress or pain, more relaxation, smiling and openness, better communication, and other emotional 
positive effects. Some patients felt deep emotions towards the social robots. Negative experiences appeared only in children on rare occasions.

- Social robots are beneficial during long periods of isolation and were of help during the pandemic. Moreover, in different environments such as school or home, telepresence provided a good quality of service.

- Although there are several ethical approaches to use robots in medicine, there is a challenge in accepting their use with children and as care workers. Differences were found depending on the context (workplace or home).

- The main ethical concerns are privacy, restraint, deception, accountability, personal space, and psychological damage. Many researchers agree that more information and data must be gathered to improve their design and interaction to overcome ethical issues.

- There are several initiatives involving ethics in technology that should be taken into account in the design of social robots for healthcare.

Regarding the design of the robot, the influence of the media factor, such as films or series, has been identified; the cultural imaginary creates expectations and prejudices towards social robots. This influence should not be taken into account in the initial phases of the design prototypes.

As we have seen, the uses of social robots are diverse, and focus on two groups (children and elderly), and very specific contexts usually associated with diseases or disabilities. However, due to the positive influence that in most cases they have on patients, and to the growing amount of literature on the subject, we predict that robot interactions will increase (i.e., expansion of emotional accompaniment, forms of communication, the performance of more types of routines), as will use contexts in hospitals (i.e., expanding contact with more types of patients and new ways of receiving patients).

Still, a question remains that should be explored: why have social robots not been widely used already in hospitals? Some reasons can be attributed to the maturity of the field of social robots, but not others. For instance, many reasons not related directly to engineering can act as barrier to the adoption of technology, including the use of robots in healthcare: for example, economic aspects, the medical staff's lack of technical knowledge, or the staff's behavioral intention $[87,88]$. Thus, the effective adoption of social robots in healthcare provides an interesting area of research to expand in the future.

Author Contributions: Conceptualization, C.S.G.-G., R.M.G.-I., and V.V.-H.; methodology, C.S.G.G., R.M.G.-I., and V.V.-H.; formal analysis, C.S.G.-G., R.M.G.-I. and V.V.-H.; investigation, C.S.G.G., R.M.G.-I., and V.V.-H.; data curation, C.S.G.-G., R.M.G.-I. and V.V.-H.; writing-original draft preparation, C.S.G.-G., R.M.G.-I., and V.V.-H. All authors have read and agreed to the published version of the manuscript.

Funding: This work has been supported by the PERGAMEX ACTIVE project, Ref. RTI2018-096986B-C32, funded by the Spanish Ministry of Science and Innovation.

Institutional Review Board Statement: Not applicable.

Informed Consent Statement: Not applicable.

Conflicts of Interest: The authors declare no conflict of interest.

\section{References}

1. Goodrich, M.A.; Schultz, A.C. Human-Robot Interaction, 1st ed.; Now: Hanover, Germany, 2008; Volume 3, ISBN 1-60198-092-2.

2. González-González, C.S.; Gil-Iranzo, R.M.; Paderewski-Rodríguez, P. Human-Robot Interaction and Sexbots: A Systematic Literature Review. Sensors 2020, 21, 216. [CrossRef] [PubMed]

3. Jung, H.-T.; Yoo, D. Towards Ethical Research Practice: Anticipating Social Consequences of Rehabilitation Robots; IEEE: Chicago, IL, USA, 2014; ISBN 978-1-4799-4992-2. [CrossRef]

4. $\quad$ Fels, D.I.; Waalen, J.K.; Zhai, S.; Weiss, P.T. Telepresence under Exceptional Circumstances: Enriching the Connection to School for Sick Children; INTERACT: Tokyo, Japan, 2001; pp. 617-624, ISBN 1-58603-188-0.

5. Vazquez-Santacruz, E.; Gamboa-Zuniga, M. A Diagnosis Methodology For Assistive Technology Development Assistive Robotics for Elderly and Disabled Patients; IEEE: Chicago, IL, USA, 2013; ISBN 978-1-4799-1460-9.

6. Aymerich-Franch, L.; Ferrer, I. The Implementation of Social Robots during the COVID-19 Pandemic. arXiv 2020, arXiv:2007.03941. 
7. Aymerich-Franch, L. Why It Is Time to Stop Ostracizing Social Robots. Nat. Mach. Intell. 2020, 2, 364. [CrossRef]

8. Javaid, M.; Haleem, A.; Vaish, A.; Vaishya, R.; Iyengar, K.P. Robotics Applications in COVID-19: A Review. J. Ind. Integr. Manag. Innov. Entrep. 2020, 5, 441-451. [CrossRef]

9. Violant-Holz, V.; Gallego-Jiménez, M.G.; González-González, C.S.; Muñoz-Violant, S.; Rodríguez, M.J.; Sansano-Nadal, O.; Guerra-Balic, M. Psychological Health and Physical Activity Levels during the COVID-19 Pandemic: A Systematic Review. Int. J. Environ. Res. Public Health 2020, 17, 9419. [CrossRef] [PubMed]

10. Yang, G.-Z.; Nelson, B.J.; Murphy, R.R.; Choset, H.; Christensen, H.; Collins, S.H.; Dario, P.; Goldberg, K.; Ikuta, K.; Jacobstein, N.; et al. Combating COVID-19-The Role of Robotics in Managing Public Health and Infectious Diseases. Sci. Robot. 2020, 5, eabb5589. [CrossRef]

11. Rogozea, L.; Leasu, F.; Repanovici, A.; Baritz, M. Ethics, Robotics and Medicine Development. In Proceedings of the 9th WSEAS International Conference on Signal Processing, Robotics and Automation, University of Cambridge, Cambridge, UK, 20-22 February 2010; pp. 264-268.

12. Page, M.J.; Mckenzie, J.E.; Bossuyt, P.M.; Boutron, I.; Hoffmann, T.C.; Mulrow, C.D.; Shamseer, L.; Tetzlaff, J.M.; Akl, E.A.; Brennan, S.E.; et al. The PRISMA 2020 Statement: An Updated Guideline for Reporting Systematic Reviews. BMJ 2021, 372, n71. [CrossRef]

13. Arana, J.; Lapresa, D.; Anguera, M.T.; Garzón, B. Ad Hoc Procedure for Optimising Agreement between Observational Records. An. Psicol. Murcia Spain 2016, 32, 589-595. [CrossRef]

14. Aria, M.; Cuccurullo, C. Bibliometrix: An R-Tool for Comprehensive Science Mapping Analysis. J. Informetr. 2017, 11, 959-975. [CrossRef]

15. Cross, E.S.; Ramsey, R. Mind Meets Machine: Towards a Cognitive Science of Human-Machine Interactions. Trends Cogn. Sci. 2021, 25, 200-212. [CrossRef]

16. Sheridan, T.B. A Review of Recent Research in Social Robotics. Curr. Opin. Psychol. 2020, 36, 7-12. [CrossRef]

17. Ngo, H.Q.T.; Le, V.N.; Thien, V.D.N.; Nguyen, T.P.; Nguyen, H. Develop the Socially Human-Aware Navigation System Using Dynamic Window Approach and Optimize Cost Function for Autonomous Medical Robot. Adv. Mech. Eng. 2020, 12. [CrossRef]

18. Moerman, C.J.; Jansens, R.M.L. Using Social Robot PLEO to Enhance the Wellbeing of Hospitalised Children. J. Child Health Care 2020. [CrossRef] [PubMed]

19. Bartlett, M.E.; Costescu, C.; Baxter, P.; Thill, S. Requirements for Robotic Interpretation of Social Signals "in the Wild": Insights from Diagnostic Criteria of Autism Spectrum Disorder. Information 2020, 11, 81. [CrossRef]

20. Benedictis, R.D.; Umbrico, A.; Fracasso, F.; Cortellessa, G.; Orlandini, A.; Cesta, A. A Two-Layered Approach to Adaptive Dialogues for Robotic Assistance. In Proceedings of the 2020 29th IEEE International Conference on Robot and Human Interactive Communication (RO-MAN), Naples, Italy, 31 August-4 September 2020; pp. 82-89.

21. Cooper, S.; Fava, A.D.; Vivas, C.; Marchionni, L.; Ferro, F. ARI: The Social Assistive Robot and Companion. In Proceedings of the 2020 29th IEEE International Conference on Robot and Human Interactive Communication (RO-MAN), Naples, Italy, 31 August-4 September 2020; pp. 745-751.

22. Turja, T.; Parviainen, J. The Use of Affective Care Robots Calls Forth Value-Based Consideration. In Proceedings of the 2020 29th IEEE International Conference on Robot and Human Interactive Communication (RO-MAN), Naples, Italy, 31 August4 September 2020; pp. 950-955.

23. Beane, M.I. In Storage, Yet on Display An Empirical Investigation of Robots' Value as Social Signals. In Proceedings of the 2020 ACM/IEEE International Conference on Human-Robot Interaction, Cambridge Guild Hall, Cambridge, UK, 23-26 March 2020; pp. 83-91. [CrossRef]

24. Moerman, C.J.; van der Heide, L.; Heerink, M. Social Robots to Support Children's Wellbeing under Medical Treatment: A Systematic State-of-the-Art Review. J. Child Health Care 2019, 23, 596-612. [CrossRef]

25. Neerincx, M.A.; van Vught, W.; Blanson Henkemans, O.; Oleari, E.; Broekens, J.; Peters, R.; Kaptein, F.; Demiris, Y.; Kiefer, B.; Fumagalli, D.; et al. Socio-Cognitive Engineering of a Robotic Partner for Child's Diabetes Self-Management. Front. Robot. AI 2019, 6, 118. [CrossRef] [PubMed]

26. Logan, D.E.; Breazeal, C.; Goodwin, M.S.; Jeong, S.; O'Connell, B.; Smith-Freedman, D.; Heathers, J.; Weinstock, P. Social Robots for Hospitalized Children. Pediatrics 2019, 144, e20181511. [CrossRef] [PubMed]

27. Melo, F.S.; Sardinha, A.; Belo, D.; Couto, M.; Faria, M.; Farias, A.; Gamboa, H.; Jesus, C.; Kinarullathil, M.; Lima, P.; et al. Project INSIDE: Towards Autonomous Semi-Unstructured Human Robot Social Interaction in Autism Therapy. Artif. Intell. Med. 2019, 96, 198-216. [CrossRef] [PubMed]

28. Hai, N.D.X.; Nam, L.H.T.; Thinh, N.T. Remote Healthcare for the Elderly, Patients by Tele-Presence Robot. In Proceedings of the 2019 International Conference on System Science and Engineering (ICSSE), Dong Hoi, Vietnam, 20-21 July 2019 ; pp. 506-510.

29. Ahn, H.S.; Yep, W.; Lim, J.; Ahn, B.K.; Johanson, D.L.; Hwang, E.J.; Lee, M.H.; Broadbent, E.; MacDonald, B.A. Hospital Receptionist Robot v2: Design for Enhancing Verbal Interaction with Social Skills. In Proceedings of the 2019 28th IEEE International Conference on Robot and Human Interactive Communication (RO-MAN), New Delhi, India, 14-18 October 2019.

30. Sequeira, J.S. Developing a Social Robot-A Case Study. Robot. Healthc. 2019, 1170, 103-125. [CrossRef]

31. Meghdari, A.; Shariati, A.; Alemi, M.; Nobaveh, A.A.; Khamooshi, M.; Mozaffari, B. Design Performance Characteristics of a Social Robot Companion "Arash" for Pediatric Hospitals. Int. J. Hum. Robot. 2018, 15, 1850019. [CrossRef] 
32. Valles-Peris, N.; Angulo, C.; Domenech, M. Children's Imaginaries of Human-Robot Interaction in Healthcare. Int. J. Environ. Res. Public Health 2018, 15, 970. [CrossRef] [PubMed]

33. Burns, R.; Jeon, M.; Park, C.H. Robotic Motion Learning Framework to Promote Social Engagement. Appl. Sci. 2018, 8, 241. [CrossRef]

34. Chen, C.; Garrod, O.G.B.; Zhan, J.; Beskow, J.; Schyns, P.G.; Jack, R.E. Reverse Engineering Psychologically Valid Facial Expressions of Emotion into Social Robots. In Proceedings of the 2018 13th IEEE International Conference on Automatic Face \& Gesture Recognition, Xi'an, China, 15-19 May 2018; pp. 448-452. [CrossRef]

35. Papadopoulos, I.; Koulouglioti, C.; Ali, S. Views of Nurses and Other Health and Social Care Workers on the Use of Assistive Humanoid and Animal-like Robots in Health and Social Care: A Scoping Review. Contemp. Nurse 2018, 54, 425-442. [CrossRef] [PubMed]

36. Um, D.; Park, J.; Shin, J.; Lee, W.H. A Social Robot, “Dali,” for Aging in Place Technology. J. Robot. 2018, 2018, 6739652. [CrossRef]

37. Dodds, P.; Martyn, K.; Brown, M. Infection Prevention and Control Challenges of Using a Therapeutic Robot. Nurs. Older People 2018, 30, 34-40. [CrossRef]

38. Larriba, F.; Raya, C.; Angulo, C.; Albo-Canals, J.; Diaz, M.; Boldu, R. Externalising Moods and Psychological States in a Cloud Based System to Enhance a Pet-Robot and Child's Interaction. Biomed. Eng. Online 2016, 15, S72. [CrossRef]

39. Shayan, A.M.; Sarmadi, A.; Pirastehzad, A.; Moradi, H.; Soleiman, P. RoboParrot 2.0: A Multi-Purpose Social Robot. In Proceedings of the 2016 4th International Conference on Robotics and Mechatronics, Tehran, Iran, 26-28 October 2016; pp. $422-427$.

40. Banthia, V.; Maddahi, Y.; May, M.; Blakley, D.; Chang, Z.; Gbur, A.; Tu, C.; Sepehri, N. Development of a Graphical User Interface for a Socially Interactive Robot: A Case Study Evaluation; IEEE: Piscatway, NJ, USA, 2016; ISBN 978-1-5090-0996-1. [CrossRef]

41. Yu, R.; Hui, E.; Lee, J.; Poon, D.; Ng, A.; Sit, K.; Ip, K.; Yeung, F.; Wong, M.; Shibata, T.; et al. Use of a Therapeutic, Socially Assistive Pet Robot (PARO) in Improving Mood and Stimulating Social Interaction and Communication for People With Dementia: Study Protocol for a Randomized Controlled Trial. JMIR Res. Protoc. 2015, 4, e45. [CrossRef] [PubMed]

42. Ono, S.; Obo, T.; Kiong, L.C.; Kubota, N. Robot Communication Based on Relational Trust Model. In IECON 2015-41st Annual Conference of the IEEE Industrial Electronics Society; IEEE: Piscatway, NJ, USA, 2015; pp. 5335-5338.

43. Goncalves, D.; Arsenio, A. Human-Driven Multi-Robot Design Process for Social Interactions with Children on Complex Environments; IEEE: Piscatway, NJ, USA, 2015; ISBN 978-1-4799-6466-6.

44. Nergui, M.; Komekine, K.; Nagai, H.; Otake, M. Development of Laughter Motion on the Cognitive Robot "Bono-02" Assisting Group Conversation; IEEE: Piscatway, NJ, USA, 2014; ISBN 978-1-4799-4266-4.

45. Ferreira, I.; Sequeira, J. When Children Interact with Robots: Ethics in the Monarch Project; IEEE: Piscatway, NJ, USA, 2014; ISBN 978981-4623-34-6.

46. Wynsberghe, A. van A Method for Integrating Ethics into the Design of Robots. Ind. Robot. Int. J. Robot. Res. Appl. 2013, 40, 433-440. [CrossRef]

47. Lewis, M.; Canamero, L. Are Discrete Emotions Useful in Human-Robot Interaction? Feedback from Motion Capture Analysis. In Proceedings of the 2013 Humaine Association Conference on Affective Computing and Intelligent Interaction, Geneva, Switzerland, 2-5 September 2013; pp. 97-102. [CrossRef]

48. Elara, M.R.; Rojas, N.; Seah, S.; Sosa, R. Design Principles for Robot Inclusive Spaces. In Proceedings of the DS 75-4: Proceedings of the 19th International Conference on Engineering Design (ICED13), Design for Harmonies, Vol. 4: Product, Service and Systems Design, Seoul, Korea, 19-22 August 2013. [CrossRef]

49. Beer, J.M.; Takayama, L. Mobile Remote Presence Systems for Older Adults: Acceptance, Benefits, and Concerns. In Proceedings of the 6th International Conference on Human-Robot Interaction, Lausanne, Switzerland, 6-9 March 2011; pp. 19-26. [CrossRef]

50. Goris, K.; Saldien, J.; Vanderniepen, I.; Lefeber, D. The Huggable Robot Probo, a Multi-Disciplinary Research Platform. In International Conference on Research and Education in Robotics; Springer: Berlin/Heidelberg, Germany, 2009; Volume 33, pp. 29-41.

51. Sutherland, C.J.; Ahn, B.K.; Brown, B.; Lim, J.; Johanson, D.L.; Broadbent, E.; MacDonald, B.A.; Ahn, H.S. The Doctor Will See You Now: Could a Robot Be a Medical Receptionist? In Proceedings of the 2019 International Conference on Robotics and Automation, Montreal, QC, Canada, 20-24 May 2019; pp. 4310-4316.

52. Van der Putte, D.; Boumans, R.; Neerincx, M.; Rikkert, M.O.; de Mul, M. A Social Robot for Autonomous Health Data Acquisition among Hospitalized Patients: An Exploratory Field Study. In Proceedings of the 2019 14th ACM/IEEE International Conference on Human-Robot Interaction (HRI), Daegu, Korea, 11-14 March 2019; pp. 658-659.

53. Sarabia, M.; Young, N.; Canavan, K.; Edginton, T.; Demiris, Y.; Vizcaychipi, M.P. Assistive Robotic Technology to Combat Social Isolation in Acute Hospital Settings. Int. J. Soc. Robot. 2018, 10, 607-620. [CrossRef]

54. Meghdari, A.; Shariati, A.; Alemi, M.; Vossoughi, G.R.; Eydi, A.; Ahmadi, E.; Mozafari, B.; Nobaveh, A.A.; Tahami, R. Arash: A Social Robot Buddy to Support Children with Cancer in a Hospital Environment. Proc. Inst. Mech. Eng. Part H J. Eng. Med. 2018, 232, 605-618. [CrossRef] [PubMed]

55. Eriksson, Y. The Perception of Aging and Use of Robots. In International Conference on Human Aspects of IT for the Aged Population; Springer: Cham, Switzerland, , 2018; Volume 10926, pp. 30-39. [CrossRef]

56. Rouaix, N.; Retru-Chavastel, L.; Rigaud, A.-S.; Monnet, C.; Lenoir, H.; Pino, M. Affective and Engagement Issues in the Conception and Assessment of a Robot-Assisted Psychomotor Therapy for Persons with Dementia. Front. Psychol. 2017, 8, 950. [CrossRef] [PubMed] 
57. Hebesberger, D.; Koertner, T.; Gisinger, C.; Pripfl, J. A Long-Term Autonomous Robot at a Care Hospital: A Mixed Methods Study on Social Acceptance and Experiences of Staff and Older Adults. Int. J. Soc. Robot. 2017, 9, 417-429. [CrossRef]

58. Shukla, J.; Barreda-Angeles, M.; Oliver, J.; Puig, D. Effectiveness of Socially Assistive Robotics during Cognitive Stimulation Interventions: Impact on Caregivers. In Proceedings of the 2017 26th IEEE International Symposium on Robot and Human Interactive Communication, Lisbon, Portugal, 28 August-1 September 2017; pp. 62-67.

59. Jeong, S.; Breazeal, C.; Logan, D.; Weinstock, P. Huggable: The Impact of Embodiment on Promoting Socio-Emotional Interactions for Young Pediatric Inpatients; IEEE: New York, NY, USA, 2018; ISBN 978-1-4503-5620-6.

60. Meghdari, A.; Alemi, M.; Khamooshi, M.; Amoozandeh, A.; Shariati, A.; Mozafari, B. Conceptual Design of a Social Robot for Pediatric Hospitals. In Proceedings of the 2016 4th International Conference on Robotics and Mechatronics (ICROM), Tehran, Iran, 26-28 October 2016; pp. 566-571.

61. Sequeira, J.S.; Ferreira, I.A. Lessons from the MOnarCH Project; IEEE: Piscatway, NJ, USA, 2016; ISBN 978-989-758-198-4.

62. Diaz-Boladeras, M.; Angulo, C.; Domenech, M.; Albo-Canals, J.; Serrallonga, N.; Raya, C.; Barco, A. Assessing Pediatrics Patients Psychological States from Biomedical Signals in a Cloud of Social Robots. In Proceedings of the XIV Mediterranean Conference on Medical and Biological Engineering and Computing, Paphos, Cyprus, 31 March 31-2 April 2016; Springer: Cham, Switzerland, 2016; Volume 57, pp. 1179-1184. [CrossRef]

63. Orejana, J.R.; MacDonald, B.A.; Ahn, H.S.; Peri, K.; Broadbent, E. Healthcare Robots in Homes of Rural Older Adults. Soc. Robot. ICSR 2015, 9388, 512-521. [CrossRef]

64. Alemi, M.; Meghdari, A.; Ghanbarzadeh, A.; Moghadam, L.J.; Ghanbarzadeh, A. Impact of a Social Humanoid Robot as a Therapy Assistant in Children Cancer Treatment. Soc. Robot. 2014, 8755, 11-22.

65. Alemi, M.; Meghdari, A.; Ghanbarzadeh, A.; Moghadam, L.J.; Ghanbarzadeh, A. Effect of Utilizing a Humanoid Robot as a Therapy-Assistant in Reducing Anger, Anxiety, and Depression. In Proceedings of the 2014 Second RSI/ISM International Conference on Robotics and Mechatronics, Tehran, Iran, 15-17 October 2014; pp. 748-753.

66. Robinson, H.; MacDonald, B.; Kerse, N.; Broadbent, E. The Psychosocial Effects of a Companion Robot: A Randomized Controlled Trial. J. Am. Med. Dir. Assoc. 2013, 14, 661-667. [CrossRef] [PubMed]

67. Boumans, R.; van Meulen, F.; Hindriks, K.; Neerincx, M.; Rikkert, M.O. A Feasibility Study of a Social Robot Collecting Patient Reported Outcome Measurements from Older Adults. Int. J. Soc. Robot. 2020, 12, 259-266. [CrossRef]

68. Hung, L.; Gregorio, M.; Mann, J.; Wallsworth, C.; Horne, N.; Berndt, A.; Liu, C. Exploring the Perceptions of People with Dementia about the Social Robot PARO in a Hospital Setting. Dement. Int. J. Soc. Res. Pract. 2019. [CrossRef]

69. Henry, J.; Leprince, T.; Robles, S.G.; Famery, A.; Boyle, H.; Gilis, L.; Witz, C.; Barland, J.-C.; Blay, J.-Y.; Marec-Berard, P. Qualitative, Exploratory, and Multidimensional Study of Telepresence Robots for Overcoming Social Isolation of Children and Adolescents Hospitalized in Onco-Hematology. J. Adolesc. Young Adult Oncol. 2020, 9, 90-95. [CrossRef]

70. Jurdi, S.; Montaner, J.; Garcia-Sanjuan, F.; Jaen, J.; Nacher, V. A Systematic Review of Game Technologies for Pediatric Patients. Comput. Biol. Med. 2018, 97, 89-112. [CrossRef]

71. Ali, S.; Samad, M.; Mehmood, F.; Ayaz, Y.; Qazi, W.M.; Khan, M.J.; Asgher, U. Hand Gesture Based Control of NAO Robot Using Myo Armband. Adv. Neuroergon. Cogn. Eng. 2020, 953, 449-457. [CrossRef]

72. Hung, L.; Liu, C.; Woldum, E.; Au-Yeung, A.; Berndt, A.; Wallsworth, C.; Horne, N.; Gregorio, M.; Mann, J.; Chaudhury, H. The Benefits of and Barriers to Using a Social Robot PARO in Care Settings: A Scoping Review. BMC Geriatr. 2019, 19, 232. [CrossRef] [PubMed]

73. Kobayashi, T.; Sameshima, N.; Imai, T.; Arai, K.; Watanabe, T.; Miyazaki, T.; Tsujino, A. Dementia Screening System Based on SNS Agency Robot. In Proceedings of the IEEE 9th International Conference on Consumer Electronics (ICCE-Berlin), Berlin, Germany, 8-11 September 2019; ISBN 978-1-72812-745-3.

74. Lindsay, S.; Hounsell, K.G. Adapting a Robotics Program to Enhance Participation and Interest in STEM among Children with Disabilities: A Pilot Study. Disabil. Rehabil. Assist. Technol. 2017, 12, 694-704. [CrossRef]

75. Chung, K.; Park, R.C. Chatbot-Based Heathcare Service with a Knowledge Base for Cloud Computing. Clust. Comput. J. Netw. Softw. Tools Appl. 2019, 22, 1925-1937. [CrossRef]

76. Ciardo, F.; Beyer, F.; Tommaso, D.D.; Wykowska, A. Attribution of Intentional Agency towards Robots Reduces One's Own Sense of Agency. Cognition 2020, 194, 104109. [CrossRef]

77. Kivrak, H.; Uluer, P.; Kose, H.; Gumuslu, E.; Barkana, D.E.; Cakmak, F.; Yavuz, S. Physiological Data-Based Evaluation of a Social Robot Navigation System. In Proceedings of the 2020 29th IEEE International Conference on Robot and Human Interactive Communication (RO-MAN), Naples, Italy, 31 August-4 September 2020; pp. 994-999.

78. Panico, F.; Cordasco, G.; Vogel, C.; Trojano, L.; Esposito, A. Ethical Issues in Assistive Ambient Living Technologies for Ageing Well. Multimed. Tools Appl. 2020, 79, 36077-36089. [CrossRef]

79. Sharif, M.S.; Alsibai, M.H. Medical Data Analysis Based on Nao Robot: An Automated Approach Towards Robotic Real-Time Interaction with Human Body; IEEE: Piscatway, NJ, USA, 2017; ISBN 978-1-5386-3897-2.

80. Beraldo, G.; Menegatti, E.; Tommasi, V.D.; Mancin, R.; Benini, F. A Preliminary Investigation of Using Humanoid Social Robots as Non-Pharmacological Techniques with Children. In Proceedings of the IEEE International Conference on Advanced Robotics and Its Social Impacts (ARSO), Beijing, China, 31 October-2 November 2019; pp. 393-400.

81. Kang, S. A Study on Smart Homecare for Daily Living Ability and Safety Management of the Elderly. Inf. Sci. Appl. 2020, 621, 707-710. [CrossRef] 
82. Stollnberger, G.; Giuliani, M.; Mirnig, N.; Tscheligi, M.; Arent, K.; Kreczmer, B.; Grzeszczak, F.; Szczesniak-Stanczyk, D.; Zarczuk, R.; Wysokinski, A. Designing User Interfaces for Different User Groups: A Three-Way Teleconference System for Doctors, Patients and Assistants Using a Remote Medical Robot. In Proceedings of the 2019 IEEE International Conference on Advanced Robotics and its Social Impacts (ARSO), Beijing, China, 31 October-2 November 2019; pp. 612-617.

83. Dutra, C.C.D.; Rocha, H.S. Religious Support as a Contribution to Face the Effects of Social Isolation in Mental Health During the Pandemic of COVID-19. J. Relig. Health 2021, 60, 99-111. [CrossRef] [PubMed]

84. Khosravi, P.; Ghapanchi, A.H. Investigating the Effectiveness of Technologies Applied to Assist Seniors: A Systematic Literature Review. Int. J. Med. Inf. 2016, 85, 17-26. [CrossRef] [PubMed]

85. Jeong, S.; Breazeal, C.; Logan, D.; Weinstock, P. Huggable: Impact of Embodiment on Promoting Verbal and Physical Engagement for Young Pediatric Inpatients. In Proceedings of the 2019 IEEE International Conference on Advanced Robotics and its Social Impacts (ARSO), New York, NY, USA, 26-31 August 2016; pp. 121-126.

86. Alemi, M.; Ghanbarzadeh, A.; Meghdari, A.; Moghadam, L.J. Clinical Application of a Humanoid Robot in Pediatric Cancer Interventions. Int. J. Soc. Robot. 2016, 8, 743-759. [CrossRef]

87. Vichitkraivin, P.; Naenna, T. Factors of healthcare robot adoption by medical staff in Thai government hospitals. Health Technol. 2021, 11, 139-151. [CrossRef]

88. Breazeal, C. Social robots for health applications. In Proceedings of the 2011 Annual International Conference of the IEEE Engineering in Medicine and Biology Society, Boston, MA, USA, 30 August-3 September 2011. [CrossRef] 